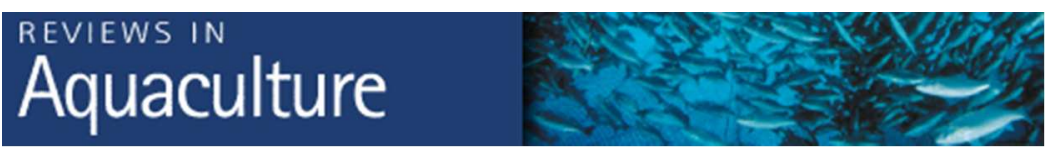

\title{
Mycotoxins in Aquaculture: Feed and Food
}

\begin{tabular}{|r|l|}
\hline Journal: & Reviews in Aquaculture \\
\hline Manuscript ID & RAQ-08-18-0084.R1 \\
\hline Manuscript Type: & Review \\
\hline Date Submitted by the Author: & $\mathrm{n} / \mathrm{a}$ \\
\hline Keywords: List of Authors: & $\begin{array}{l}\text { Gonçalves, Rui A.; BIOMIN Holding GmbH, Aquaculture; University of } \\
\text { Stirling, Institute of Aquaculture } \\
\text { Schatzmayr, Dian ; BIOMIN Research Center } \\
\text { Albalat, Amaya ; University of Stirling, Institute of Aquaculture } \\
\text { MacKenzie, Simon ; University of Stirling, Institute of Aquaculture }\end{array}$ \\
\hline & $\begin{array}{l}\text { mycotoxins occurrence, carry-over effects, fish, Shrimp, aquafeeds, } \\
\text { transfer factor }\end{array}$ \\
\hline
\end{tabular}

\section{SCHOLARONE ${ }^{\text {m }}$}

Manuscripts

This is the peer reviewed version of the following article: Gonçalves, R.A., Schatzmayr, D., Albalat, A. and Mackenzie, S. (2020), Mycotoxins in aquaculture: feed and food. Reviews in Aquaculture, 12: 145-175, which has been published in final form at https://doi.org/10.1111/raq.12310. This article may be used for non-commercial purposes in accordance with Wiley Terms and Conditions for self-archiving. 


\title{
Mycotoxins in Aquaculture: Feed and Food
}

\author{
Rui A. Gonçalves ${ }^{1,3^{*}}$, Dian Schatzmayr ${ }^{2}$, Amaya Albalat $^{3}$, Simon Mackenzie ${ }^{3}$ \\ ${ }^{1}$ BIOMIN Holding GmbH, Erber Campus 1, 3131 Getzersdorf, Austria \\ ${ }^{2}$ BIOMIN Research Center, Technopark 1, 3430 Tulln, Austria. \\ ${ }^{3}$ University of Stirling, Institute of Aquaculture, Stirling, United Kingdom. \\ *corresponding author: Email: rui.goncalves@biomin.net
}

\section{Abstract}

Mycotoxins, secondary metabolites produced by molds, are responsible for causing significant economic losses due to spoilage of agricultural products but also due to direct or indirect health impact on livestock upon ingestion of mycotoxin contaminated feedstuffs. Aquaculture farmed species are not an exception and studies reporting mycotoxin-related issues in the aquaculture industry have been increasing. However, our understanding on the prevalence and impact of mycotoxins in the aquaculture sector is still lower compared to the terrestrial livestock sector. Consequently, regulatory limits and guidance values have been defined based on the studies on terrestrial farm animals.

The aim of this review is to compile and critically assess mycotoxin occurrence and cooccurrence in aquaculture finished feeds, and understand the risk of mycotoxin carry-over in aquaculture seafood products. Furthermore, we aim with this review to raise awareness to the scientific community, the regulatory authorities and the aquaculture industry to the need for specific aquaculture mycotoxin maximum concentration levels for both aquaculture feeds and foods.

Keywords: mycotoxins occurrence; carry-over effects; fish; shrimp; aquafeeds; transfer factor 
1

2 Mycotoxin abbreviations:

3 AFs: aflatoxins; meaning the sum of $A F B_{1}, A F B_{2}, A F G_{1}$ and $A F G_{2}$

$4 \quad \mathrm{AFB}_{1}$ : aflatoxin $\mathrm{B}_{1}$

$5 \quad \mathrm{AFB}_{2}$ : aflatoxin $\mathrm{B}_{2}$

$6 \quad \mathrm{AFG}_{1}$ : aflatoxin $\mathrm{G}_{1}$

$7 \quad \mathrm{AFG}_{2}$ : aflatoxin $\mathrm{G}_{2}$

8 DON: deoxynivalenol

9 ENNs: enniatins

10 FUM: fumonisins; meaning the sum of $\mathrm{FB}_{1}$ and $\mathrm{FB}_{2}$

$11 \mathrm{FB}_{1}$ : fumonisin $\mathrm{B}_{1}$

$12 \quad \mathrm{FB}_{2}$ : fumonisin $\mathrm{B}_{2}$

13 OTA: ochratoxin A

14 ZEN: zearalenone

15 a-ZEL: alpha-Zearalenol

$16 \quad \beta$-ZEL: beta-Zearalenol

17

18 Other abbreviations:

19 TF - Transfer factor

20 DN - Denmark

21 AT - Austria

$22 \mathrm{NL}$ - the Netherlands

23 DE - Germany

24 VN - Vietnam

25 ID - Indonesia

26 MM - Myanmar 
Mycotoxins are secondary metabolites produced by some molds (Hussein and Brasel, 2001). These can be produced on agricultural commodities pre- and/or post-harvest including directly in finished feeds. Mycotoxins are responsible for significant economic losses due to the spoilage of agricultural products (CAST, 2003; Shane and Eaton, 1994; Vasanthi and Bhat, 1998). Furthermore, mycotoxins can cause diseases problems when consumed by humans and livestock, causing significant problems worldwide (Zain, 2011). Despite being identified as categorically undesirable for most aquaculture species, their occurrence, at least in field conditions, is not completely preventable even when using good manufacturing practices (FAO 1979). The awareness of mycotoxin-related issues in the aquaculture industry has been increasing, accentuated by the increased inclusion levels of plant meals in aquafeeds (Tacon et al. 2011). Traditionally, the use of minor amounts of plant feed stuffs led to an accepted perception that mycotoxins were not a relevant issue in aquaculture and that the majority of mycotoxin issues would stemmed only due to poor storage conditions. Aspergillus spp. and Penicillium spp. can grow on feed stored in poor conditions, ultimately leading to the production of aflatoxin (AF) and ochratoxin A (OTA). This would seem to be particularly the case in countries where climate conditions are favourable to the growth of Aspergillus spp. and Penicillium spp. fungi. However, optimal storage conditions should prevent the contamination of raw materials and finished feeds from AF or OTA. However, some plant commodities such as cottonseed and peanut meals commonly present detectable levels of AF and/or OTA (Gonçalves et al. 2017), even when stored using appropriate conditions. With the increased use of plant meals in aquafeeds, other mycotoxins besides AF and OTA have been reported in finished feeds, as mycotoxins are reasonably stable to processing conditions (Cheli et al. 2013). Fusarium mycotoxins (Type B and A, trichothecenes and fumonisins) are, contrary to AF and OTA, mainly produced at pre-harvest stage. The production of these mycotoxins by Fusarium spp. seems to be highly influenced by environmental conditions, so an increase in occurrence is expected due to climate change (Miraglia et al. 2009; Paterson and Lima, 2010; Paterson and Lima, 2011). This contamination may potentially cause harm to the fish and shrimps, dependent upon mycotoxin concentration and co-occurrence, consequently resulting in significant economic losses, directly (e.g., mortality or decreases in performance), or indirectly (e.g. higher susceptibility to diseases). However, one of the biggest barriers to quantify the impact of mycotoxin 
contamination in the aquaculture industry is the apparent lack of clinical signs or biomarkers in aquatic species for mycotoxin exposure, especially compared to terrestrial livestock. While several reports describe broad and non-specific clinical signs for the most common mycotoxins (see review from Anater et al. (2016)), these lack specificity and could be attributed to a number of pathologies or challenges such as the presence of anti-nutrition factors or lectins in the diet (Hart et al. 2010). The case of aflatoxicosis, (yellowing of the body surface, (Deng et al. 2010) and ingestion of fumonisins (FUM; alteration of the sphinganine to sphingosine ratio, (Tuan et al. 2003)) are two notable exceptions. Also, Gonçalves et al. (2018b) described DON-3-sulfate as a potential biomarker of deoxynivalenol (DON) exposure in rainbow trout (Oncorhynchus mykiss).

Carry-over denotes the conveyance of undesired compounds from contaminated feed into food of animal origin. The potential of carry-over of several mycotoxins in terrestrial animals such as poultry, swine and cows issue was highlighted by the European Food Safety Authorities (EFSA) and FAO (Domenico Caruso et al. 2013; EFSA, 2004b FAO, 2001)). However, no guidelines are available regarding carry-over in farmed fish and shrimp species. Therefore, the present review aims to compare the mycotoxin occurrence and cooccurrence in aquaculture finished feeds with the potential risk of mycotoxin carry-over in aquaculture seafood products across main aquaculture produced species. Furthermore, we aim to critically compare carry-over obtain in aquaculture species to the ones obtained for livestock species. With this review, we intend to raise awareness to the scientific community, the regulatory authorities and the aquaculture industry to the possible need for specific aquaculture mycotoxin maximum concentration levels for both aquaculture feeds and foods. Furthermore, authors aware for particular cases in aquaculture sector, where edible tissues may change in different regions, therefore increasing the risk of mycotoxicosis.

\section{OCCURRENCE OF MYCOTOXINS IN AQUAFEEDS}

The high cost and limited availability of fishmeal has led the aquaculture industry to gradually increase the levels of alternative protein sources as a substitute for fishmeal in their feeds (Davis and Sookying, 2009). Overall, a wide range of products, e.g. animal byproducts, fishery by-products, insect meals, macro-algae meals or single-cell protein, have been explored as alternatives to fishmeal. However, for several reasons (e.g., production scalability, market availability, batch uniformity or price competitiveness) plant-based meals 
91

remain the most widely used alternative protein source. When considering plant-based meals for aquafeeds, it is commonly agreed that one of the negative aspects is the presence of anti-nutrients (e.g. cyanogens, saponins, tannins etc.) which are detrimental to fish and shrimp (Krogdahl et al. 2010). Conversely, the negative impact of mycotoxins is often overlooked. The disbelief in the negative effects of mycotoxins on aquatic species might be related to the lack of observable clinical signs in aquatic species directly related to mycotoxin ingestion compared to terrestrial livestock species where the effects are more pronounced. However, the awareness of mycotoxin-related issues in the aquaculture industry has grown in recent years as feed manufacturers and producers have recognised the importance of mycotoxins and their potential to impact production, final product quality (García-Morales et al. 2013) and safety for consumers (Michelin et al. 2017). The evolution of the analytical platforms used to detect mycotoxins and the easier access to analytical labs or simple ELISA strip tests kits for in situ testing, has also increased the awareness of mycotoxins to feed millers and farmers.

During the revision of the peer-reviewed literature on the occurrence of mycotoxins in aquafeeds, summarized in this review, a pattern of the target mycotoxins analysed in feed samples emerged. In samples analysed before 2012 , the main mycotoxins analysed were AFs $\left(A F B_{1}, A F B_{2}, A F G_{1}, A F G_{2}\right.$; in most of the cases only $A F B_{1}$; see Table 1) and in some cases zeralenone (ZEN) and OTA (Fegan and Spring 2007) (with the exception of (Martins et al. 2008) and, possibly based on previous data reported on terrestrial livestock feed samples. After 2012, other mycotoxins were beginning to be reported besides AF's (Table 1). These studies have either targeted the analysis of specific mycotoxins due to the inclusion of certain plant meals (e.g., (Pietsch et al. 2013; Woźny et al. 2013) or explored a broad mycotoxin occurrence (Gonçalves et al. 2018a; Gonçalves et al. 2018; Gonçalves et al. 2017; Nácher-Mestre et al. 2015). This different pattern in the target mycotoxin analysed in feed might be a reflection of increasing awareness of mycotoxins in aquaculture, but also as a result of the easier access to mycotoxin analytical methods.

\section{Aquafeed studies with samples preceding 2012}

The oldest documented survey of mycotoxin occurrence in aquaculture finished feed was by Bautista et al. (1994). In this study, a total of 62 samples collected in the Philippines between August 1990 to February 1991 from black tiger shrimp (Penaeus monodon) feed, sourced 
123 from feed mills and at farm level were analysis (Table 1). The authors observed that only two 124 of the 62 samples were free from AFs, 36 samples were contaminated with AFs at levels between 10 and $20 \mu \mathrm{g} \mathrm{kg}^{-1}, 21$ samples contained AFs at levels between 30 and $40 \mu \mathrm{gg}^{-1}$ and two samples had AFs levels of 60 and $120 \mu \mathrm{gg}^{-1}$. The second study was from Bintvihok et al. (2003) which analysed samples collected in the eastern and southern regions of Thailand (1997 to 1998) and by Altuğ and Berklevik (2001) with samples collected in Turkey from 1998 to 2000 (Table 1). Bintvihok et al. (2003) analysed 150 samples of commercial shrimp feed (formulated for Penaeus monodon) composed mainly of fishmeal, soybean and corn. Samples were collected directly from farms in ten different provinces during the summer months (March to June 1997), the rainy season (July to October 1997) and the winter (November to February 1998) and analysed for $A F B_{1}, A F B_{2}, A F G_{1}$ and $A F G_{2}$. Bintvihok et al. (2003) observed that feed was more frequently contaminated in the eastern region (43 contaminated out of 75 collected samples) compared to the southern region (14 contaminated out of 75 collected samples). Contamination also occurred more frequently during rainy season (29 contaminated out of 50 collected samples) followed by winter (20 contaminated in 50 collected samples). $\mathrm{AFB}_{1}$ was the most prevalent mycotoxin found in samples, although at relatively low concentrations $\left(<1 \mu \mathrm{kg}^{-1}\right.$; Table 1$)$. However, the study lacked information regarding levels of inclusion of the plant ingredients as well as storage time and conditions prior to analysis, which does not allow drawing further conclusions regarding the origin of the AF contamination (i.e., from raw materials or contamination during storage). Soybean and corn are not typically contaminated with AFs, at least in the field, as these plant commodities are more likely contaminated with DON, FUM and ZEN (Gonçalves et al. 2018a). Therefore, AF contamination in finished feeds could reflect inadequate storage conditions of raw materials or feeds. Reporting inclusion levels of plant ingredients would be very useful. Importantly, Altuğ and Berklevik (2001) analysed 170 fish finished feed samples for the presence of $\mathrm{AFB}_{1}$ in Turkey between 1998 and 2000. Samples were collected at farm level, feed mills or imported feeds. In this study, AFB $B_{1}$ was found below detection limits in 43 samples ( $25.2 \%$ of samples), in 20 samples (11.7\% of samples) $\mathrm{AFB}_{1}$ levels were above $20 \mu \mathrm{g} \mathrm{kg}^{-1}$ and in 85 samples ( $50 \%$ of samples) $\mathrm{AFB}_{1}$ ranged between 21.2 to $42.4 \mu \mathrm{g} \mathrm{kg}^{-1}$. Authors from this study concluded that levels of $\mathrm{AFB}_{1}$ were higher in samples taken from farms compared to feed mill or imported feed samples. 
154 Fegan and Spring (2007) reported, to our knowledge, the first and most complete mycotoxin occurrence survey on fish and shrimp feeds before 2012. Samples were collected in India and Thailand and analysed for the presence of AFs, T-2, ZEN and OTA. No information is available on the period of sampling, region area or sample origin (feed mill or farm). Nonetheless, the information reported shows a different contamination pattern between fish and shrimp feeds and also shows co-occurrence of mycotoxins. Out of the nine fish feed samples analysed from Thailand, all samples were contamination predominantly by ZEN, at levels ranging from 36.20 to $118.48 \mu \mathrm{g} \mathrm{kg}^{-1}$, followed by T-2 (2.6 to $50.03 \mu \mathrm{g} \mathrm{kg}$ ) and OTA (2.32 to $\left.7.74 \mu \mathrm{g} \mathrm{kg}^{-1}\right)$. Also in Thailand, shrimp feed samples $(n=7)$ were contaminated with ZEN and OTA while no data on AFs was available (Table 1). Shrimp feed samples $(n=10)$ collected from India were mostly contaminated with AFs, ranging between 40 and $90 \mu \mathrm{g} \mathrm{kg}{ }^{-1}$. However, it is important to mention that levels of sensitivity are mycotoxin-specific and therefore although OTA reported levels were in general lower than ZEN, aquatic species are more sensitive to OTA (see Gonçalves et al. 2018 for sensitivity levels in aquatic species). In their study, Fegan and Spring (2007) also reported mycotoxin occurrence in the raw materials used to formulate aquafeeds. While the objective of the present review is only to report mycotoxin occurrence in finished feed, it is inevitable and fundamental to highlight the occurrence of mycotoxins (T-2 and ZEN and OTA) in marine ingredients (fishmeal from China, Myanmar, Thailand; fish and shrimp meal from Thailand) which will be further discussed in next sections.

An exception to the almost exclusive AF analysis in finished feeds prior to 2012, are the results presented by Martins et al. (2008), who analysed 20 samples of fish feed sourced from Portugal for the presence of $\mathrm{AFB}_{1}, \mathrm{OTA}, \mathrm{DON}, \mathrm{ZEN}$ and fumonisin $\mathrm{B} 1\left(\mathrm{FB}_{1}\right)$. In this study, no detectable levels of the target mycotoxins were obtained.

In the remaining studies shown in Table 1, in which samples were collected in or before 2012 (Alinezhad et al. 2011; Almeida et al. 2011; Gonçalves-Nunes et al. 2015), the target mycotoxin analysed in feed was always $A_{F B}$. Almeida et al. (2011), did not detect $A F B_{1}$ in the 87 samples of seabass feed collected in Portugal. Interestingly, 35 of the 87 samples analysed were contaminated with Aspergillus spp., which highlights that the presence of fungi does not necessarily mean the presence of the toxin and vice-versa. Alinezhad et al. (2011), detected levels high concentrations of $\mathrm{AFB}_{1}$ in fishmeal (average $=67.35 \mu \mathrm{g} \mathrm{kg}^{-1}$ ). In 
Brasil, Gonçalves-Nunes et al. (2015), reported the presence of $\mathrm{AFB}_{1}$ ranging from 1.6 to 9.8 $\mu \mathrm{g} \mathrm{kg}{ }^{-1}$ in samples collected directly at the feed plant.

From 2012 onwards, the number of peer-reviewed publications and technical articles (not covered in this review) related to the presence of mycotoxins (including not only AFBs) in aquaculture feeds increased considerably. In 2013, Woźny et al. (2013) analysed the presence of ZEN in trout feed collected from three farms in November. One of the farms had no detected levels of ZEN while the other two farms had $81.8 \pm 25.8$ and $10.3 \pm 0.9 \mu \mathrm{gg}^{-1}$ of ZEN in their feed respectively. The same study also explored the carry-over of ZEN from feed by analysing several rainbow trout (Oncorhynchus mykiss) organs for ZEN presence, results that are further explored in next section. Pietsch et al. (2013), unveiled the presence of DON $\left(236.18 \mu \mathrm{g} \mathrm{kg}^{-1}\right.$ ) and ZEN (63.82 $\mathrm{g} \mathrm{kg} \mathrm{k}^{-1}$ ) in common carp (Cyprinus carpio) feeds in samples from central Europe. Still in Europe, Nácher-Mestre et al. (2015), investigated the occurrence of mycotoxins in Atlantic salmon (Salmo salar) and gilthead sea bream (Sparus aurata) feeds, with respectively, high and low inclusion of plant meals. From the 18 mycotoxins analysed, the most representative mycotoxins found were FUM and DON. In Atlantic salmon, from the three types of feeds analysed, levels of DON were 22.4, 19.4 and $23.1 \mu \mathrm{g} \mathrm{kg}^{-1}$ and 148,754 and $112 \mu \mathrm{g} \mathrm{kg}^{-1}$ of FUM respectively. For gilthead sea bream, two samples were found to contain 79.2 and $53.5 \mu \mathrm{g} \mathrm{kg}^{-1}$ of DON, and $6.4 \mu \mathrm{g} \mathrm{kg}$-1 of FUM in only one of the samples. In Argentina, Greco et al. (2015) also analysed salmonids feeds. In this study, 28 samples of rainbow trout (Oncorhynchus mykiss) feed were sampled at the farms, ranging throughout the feed portfolio for different development stages (starter feed (13 samples); grower feed (13 samples); 4 pigmented and 9 unpigmented feed and finisher feed ( 2 pigmented samples). The authors observed median values of: AFs $=2.82 ;$ OTA $=5.26 ; \mathrm{T}-2$ $=70.08 ; \mathrm{DON}=230$ and ZEN $=87.97 \mu \mathrm{kg}^{-1}$. It was also highlighted that, there was a cooccurrence of at least two out of six mycotoxins in $93 \%(26 / 28)$ of the analysed samples. Gonçalves et al. (2018a; 2018; 2017) focused on unveiling the mycotoxin occurrence in plant meals (not reported here) and aquaculture finished feeds in Europe and Southeast Asia. In 2014, from January to December, 41 fish and shrimp feed samples were collected from Europe ( $n=6$ to 10; Croatia and Portugal) and SE Asia ( $n=31$; Singapore, India, Thailand and 
Myanmar). Samples were analysed for AFs, ZEN, DON, FUM and OTA (Table 1). Interestingly, a higher occurrence of FUM was found in European samples (average 3419.92 and maximum $7533.61 \mu \mathrm{g} \mathrm{kg}^{-1}$ ) compared to SE Asia. The remaining mycotoxins showed similar occurrence average and maximum levels for Europe and SE Asia, with mycotoxins being detected in all analysed samples. In this mycotoxin survey (Gonçalves et al. 2018), it was reported that in Europe, $50 \%$ of the samples had more than one mycotoxin per sample, and in Asia, $84 \%$ of the samples were contaminated with more than one mycotoxin per feed sample. In 2015, analysing the same mycotoxins as in the previous study, Gonçalves et al. (2017) sourced 25 samples of fish and shrimp feeds in Europe $(n=4$; Denmark, Austria, Netherlands and Germany) and SE Asia ( $\mathrm{n}=21$; Vietnam, Indonesia, Myanmar). Contrary to samples collected in 2014, the European samples analysed in 2015 showed relatively low mycotoxin contamination, with only DON contamination reaching values up to $20 \mu \mathrm{gg}^{-1}$. In SE Asian samples, contamination was also generally lower when compared to the previous year, with only AFs showing similar contamination levels to 2014 (average contamination of $58 \mu \mathrm{g} \mathrm{kg}^{-1}$ and maximum of $201 \mu \mathrm{g} \mathrm{kg}^{-1}$ ). However, the co-occurrence risk increased in both regions. From January to December 2016, Gonçalves et al. (2018a) sampled four shrimp feeds from India and 12 fish feeds from Indonesia, Myanmar, Taiwan and Thailand. Interestingly, the fish and shrimp feeds showed a relatively different mycotoxin contamination pattern, possibly due to the type of raw materials used to manufacture these diets. Fish feed samples showed lower contamination (Table 1), when compared with shrimp feeds. However, a higher number of co-occurring mycotoxins were observed in fish feeds. Shrimp feeds showed a relatively high contamination of DON, with an average contamination level of 881.66 and maximum of $2287 \mathrm{\mu g} \mathrm{kg}^{-1}$. Mycotoxins also represent a big challenge to the increasingly successful aquaculture sector on the African continent. Marijani et al. (2017), analysed mycotoxin occurrence in Nile tilapia (Oreochromis niloticus) and African catfish (Clarias gariepinus) feeds, gathering 16 samples from Kisumu, Kenya, 13 samples from Ukerewe, Tanzania, 10 samples from Kigembe, Rwanda and 13 samples from Jinja, Uganda. Samples were collected from farms (farm-made feeds; $n=14)$, local feed millers $(n=14)$ or imported feeds from Israel and India $(n=12)$. From the 52 samples analysed, Marijani et al. (2017) observed that farm-made feeds were highly contaminated with AF, FUM and DON (Table 1). On the other hand, feed samples from local feed millers, as well as the imported feed samples, had only minor contamination of AF. 
From the documented peer-reviewed literature, it is possible to observe a growing interest in the occurrence of mycotoxins in aquatic feeds. It is also observable that there is a shift regarding the target mycotoxins analysed in feeds. Most of the earlier studies evaluating mycotoxins in aquafeeds (Bintvihok et al., 2003, Altuğ and Berklevik, 2001) mainly focused on aflatoxin occurrence and only in recent years, other mycotoxins were analysed. This research pattern, i.e., high focus on AFs and only later on other mycotoxins, can also be observed in the peer-reviewed literature studying the impact of mycotoxins in aquatic animal health and performance (Gonçalves et al. 2018). The increasing interest in mycotoxins in aquafeeds, and particularly the interest in other mycotoxins besides AFs, is certainly related to the increasing inclusion levels of plant meals in aquafeeds, as well as, the awareness of mycotoxins conveyed from these plant meals to aquafeeds. However, we cannot exclude the easier access to analytical instrumentation to determine mycotoxins together with the evolution of the analytical methods per se as a plausible contribution to this shift.

The results of the most recent mycotoxin occurrence surveys of aquaculture feeds (Gonçalves et al. 2018a; Gonçalves et al. 2018; Gonçalves et al. 2017; Marijani et al. 2017; Nácher-Mestre et al. 2015) clearly show an increase in mycotoxin occurrence compared to previous surveys (Alinezhad et al. 2011; Almeida et al., 2011; Altuğ and Berklevik, 2001; Bintvihok et al. 2003). Unfortunately, it cannot be concluded, from this data, that there is a higher mycotoxin risk now compared to the past. This is because the target mycotoxins analysed in older studies were not the same and sensitivity detection levels and methodologies have since improved significantly. Nonetheless, it was theoretically expected that an increasing level of plant meals in aquafeeds would lead to increased occurrence of mycotoxins in these feeds, which is observable by the most recent occurrence surveys (Gonçalves et al. 2018; Gonçalves et al. 2018; Gonçalves et al. 2017; Marijani et al. 2017; Nácher-Mestre et al. 2015).

276 Besides the increasing mycotoxin occurrence and the focus on a broad range of mycotoxins, several other important conclusions can be taken from the studies summarized in Table 1. A key aspect is the regional differences in mycotoxin occurrence reported and the correlation between fungi contamination and the presence of mycotoxins. The presence of molds in a 
280

281

282

283

284

285

286

287

288

289

290

291

292

293

294

295

296

297

298

299

300

301

302

303

304

305

306

307

308

309

310

311

fish feed is the first indication that something is wrong with its hygiene. There are several reasons why feeds get moldy, from improper storage conditions (high humidity, high variations in temperatures leading to condensation, etc) to poor manufacturing process (e.g., insufficient drying time, lack of perservatives/anti-molds, etc). Fungi contamination can also originate from inappropriate selection of ingredients, which can carry fungi spores that are resistant to extrusion/pelleting, having the capacity to germinate afterwards (due to improper storage or poor manufacturing processes).

While the presence of fungi might be a direct risk for the host, e.g., Fusarium oxysporum and Fusarium solani, known as opportunistic pathogens for fish and shrimp (Hatai et al. 1986; Lightner, 1996; Ostland et al. 1987; Souheil et al. 1999), and an indirect risk which reduces the palatability and therefore intake of the feed, its presence does not necessarily correlate with the presence of the toxin producer mold and vice-versa (Alinezhad et al. 2011; Greco et al. 2015). On the other hand, mycotoxins produced on crops in the field will remain in raw materials, even after processing, due to their heat stability (Pitt, 2014), while fungi will be destroyed due to high temperatures. For example, Fusarium spp. are field fungi usually lacking the ability to grow on dry feed. However, the toxins produced by these fungi species (e.g., DON, FUM) will remain stable on the plant raw materials used to manufacture aquafeeds, and in some cases, even be redistributed and concentrated in certain milling fractions (Cheli et al. 2013) e.g, corn vs corn gluten meal (Gonçalves et al. 2018a). Mycotoxin redistribution and transfer from crops to aquafeeds has been observed and reported by Gonçalves et al. (2018a). While it is not the core of the present review, we need to highlight that, with the exception of AF and OTA, most of the other mycotoxins found in the occurrence surveys and shown in Table 1 are probably due to the use of plant meals rather than mycotoxins being produced during storage. So, the selection and analysis of the plant raw materials selected to manufacture aquafeeds is the first step to minimise mycotoxin accumulation risks in aquafeeds.

The regional differences in mycotoxin occurrence is also an important factor which cannot be overlooked. Fungal growth, and consequently mycotoxin production in crops, is influenced by several factors, with weather conditions being the most important (Miraglia et al. 2009; Paterson and Lima, 2010; Paterson and Lima, 2011). Consequently, it could be expected that different regions present differences in mycotoxin contamination patterns, and even within a region, mycotoxin occurrence may vary depending on seasonal conditions. 
312 This is shown by the data reported by Bintvihok et al. (2003) in samples from Thailand, which

313 suggests that rainy seasons might be more problematic and therefore should be closely

314 monitored. However, factors such as climate change and the world trade of commodities

315 makes it challenging to estimate the risk of mycotoxins in aquaculture finished feeds. For 316 example, as reported by Gonçalves et al. (2018), higher levels of FUM in European finished

317 feeds compared to SE Asia samples cannot be easily explained and therefore a better

318 understanding on the origin of sourced ingredients is necessary. The increasing globalisation

319 of trade commodities and incorporation of imported raw materials into aquafeeds exposes

320 the industry to the potential risk of mycotoxins, which are sometimes not even common for

321 the region (not the case in that particular study). Therefore, mycotoxin contamination needs

322 to take into account the globalisation of raw materials, which could already have significant

323 levels of mycotoxins together with the monitoring of finished feeds.

324

\section{EMERGING MYCOTOXINS}

Emerging mycotoxins are a class of mycotoxins which its occurrence in feed and food commodities has been increasing only recently (Kovalsky et al. 2016) and which may represent a potential toxicity towards animals and humans. The presence of these mycotoxins also produced by Fusarium spp. (as are DON, FUM and ZEN described previously) is expected to increase due to climate change (Miraglia et al. 2009; Paterson and Lima, 2010; Paterson and Lima, 2011). However, quantitative estimates of their occurrence are scarce, especially in aquaculture feeds. While for trichothecenes, data on its toxicity, occurrence, and contamination levels are available, reported in previous section, for other metabolites also produced by Fusarium spp., such as moniliformin (MON), fusaproliferin (FUS), beauvericin (BEA) or enniatins (ENNs), limited information is available. Moreover, the typical Fusarium mycotoxins (DON, FUM and ZEN) are legislated for certain levels in feed commodities, however, for this new diverse group of "emerging toxins" e.g., MON, FUS, BEA and ENNs, legislation is scarce (Kovalsky et al., 2016). Besides that, the effects of these mycotoxins on aquaculture species is still relatively unknown (Gonçalves et al. 2018; Jestoi, 2008; Nguyen et al. 2003; Tuan et al. 2003; Yildirim et al. 2000). Generally, is observed that, regulated mycotoxins, i.e., FUM, DON and ZEN occurrence levels in feeds are still higher than these emerging mycotoxins (Kovalsky et al. 2016). However, Tolosa et al. (2013) identified several enniatins (ENNs; ENA1, ENB and ENB1) in seabream, seabass, tilapia and panga 
tissues from commercialized aquaculture fishes. To our knowledge, Tolosa et al. (2013) study is the first of its kind and highlights for the need to better understand mycotoxin carry-over beyond the typical Fusarium spp. mycotoxins. This topic will be further discussed in section "Data obtained from commercially sourced aquaculture products".

\section{Bioaccumulation of mycotoxins from feed to animal food products might represent a direct} risk to human health (CAST 2003). Mycotoxin bioaccumulation in livestock is well investigated (I. Völkel et al. 2011; Leeman et al. 2007) and the risk to humans is currently being evaluated by the European Food Safety Authority (EFSA) for several mycotoxins (AF, OTA, ZEN, DON, FUM, T-2 and HT-2). Bioaccumulation of mycotoxins in poultry, swine and cows is managed by direct regulation of mycotoxins in animal feed (EC, 2006; EFSA, 2004a; EFSA, 2004d; EFSA, 2004c; EFSA, 2005; EFSA, 2011; EFSA, 2013). While regulatory limits have been put in place for AFs (), only guidance values are available for DON, OTA, FUM and zearalenone (ZEN; EC, 2006). This is because feed does not represent a direct risk for human health and because carry-over of these mycotoxins in terrestrial animals is expected to be low (EC. 2006).

Currently, no regulations or guidelines exist in order to avoid deposition of mycotoxins in farmed fish or shrimp, with the exception of fumonisins (FB1 + FB2 $=10 \mathrm{mg} \mathrm{kg}^{-1}$; EC. 2006). Moreover, it is not taken into consideration that carry-over mechanisms in aquaculture farmed species might be different from terrestrial livestock species. Generally, the possibility of mycotoxin bioaccumulation/biomagnification through the food chain due to the use of mycotoxin contaminated non-plant origin ingredients such as animal by-products (e.g., shrimp head meal or chicken droppings (further discussed in section "Carry-over data obtained from feeding trials"; "Aflatoxins")) or non-typical mycotoxin contaminated ingredients (e.g., fishmeal), is not taken into consideration and will be addressed during this review.

Bioaccumulation of mycotoxins in aquaculture seafood products is not widely reported and consequently not regulated. This section will focus on documented peer-reviewed mycotoxin carry-over studies focussed in aquaculture species. Existing literature is reviewed, calculating transfer factors when the available data allows it, in order to compare 
375 bioaccumulation risks (Leeman et al. 2007). The transfer factor is expressed as the

376 concentration of mycotoxin in animal tissues $\left(\mu \mathrm{g} \mathrm{kg}^{-1}\right)$ divided by the concentration of the same mycotoxin in animal feed $\left(\mu \mathrm{kg}^{-1}\right)$.

Carry-over data obtained from feeding trials

The present section intends to give an overview of studies reporting the carry-over of mycotoxins from feed to animal tissues, assessed in feeding trials with supplemented mycotoxins in feed. We calculated transfer factors for carry-over of mycotoxins from feed to eggs, whole milk, meat and edible offal as calculated by Leeman et al. (2007) (Table S1). The data presented by Leeman et al. (2007) covered 250 references resulting in a comparison of 3624 transfer factors from livestock species (cattle, poultry, pig, sheep, goat, rabbit, pheasant, turkey, duck and quail). These authors took into account the carry-over of AFs $\left(\mathrm{AFB}_{1}, \mathrm{AFB}_{2}, \mathrm{AFG}_{1}\right.$ and $\left.\mathrm{AFG}_{2}\right), \mathrm{DON}, \mathrm{OTA}, \mathrm{T}-2$ and $\mathrm{ZEN}$. Leeman et al. (2007) reported average transfer factors, ignoring the differences in different mycotoxin kinetics as well as the different metabolism capacity of animals. Nonetheless, the information gathered has a high relevance and allows a first comparison between transfer factors in aquaculture-farmed species versus livestock.

Aflatoxin bioaccumulation from feed to animal tissues is well documented for aquaculture species. A total of 19 studies have evaluated the presence of AFs in fish and crustacean tissues after being fed a certain amount of this same mycotoxin (Table 2). The first study (Suzy et al. 2017) reported in Table 2 raises an interesting and not yet discussed point about the occurrence of mycotoxins in feed conveyed from animal byproducts and not necessarily from plant meals. Suzy et al. (2017) reported that with increasing aquaculture production in Africa, in this case the West Cameroon region, feed ingredients are a serious limitation to the sustainable growth of the aquaculture sector. The author reported that due to the good protein content, chicken droppings were being used as an ingredient in the local fish food or as direct feed, despite its contamination with AF's. Suzy et al. (2017) reported that after feeding African sharptooth catfish (Clarias gariepinus) with 10, 17 and $20 \mu \mathrm{g} \mathrm{AFB} \mathrm{kg}^{-1}$, for three months, $0.05 \pm 0.12,0.08 \pm 0.10$ and $0.08 \pm 0.12 \mu \mathrm{g}$ 
406 factors (0.004-0.005) (Table 2) for AF in the muscle are within range to values reported for 407 eggs and meat (Leeman et al. 2007).

Regarding cold/temperate water reared species, five studies are available; in European seabass (Dicentrarchus labrax) (El-Sayed and Khalil, 2009)), hybrid sturgeon (Acipenser ruthenusx A. baeri) (Rajeev Raghavan et al. 2011), walleye fish (Sander vitreus) (Hussain et al. 1993) and rainbow trout (Oncorhynchus mykiss) (Ellis et al. 2000; Ngethe et al. 1992; Ngethe et al. 1993)) (Table 2). Studies in rainbow trout so far have used tritium $\left({ }^{3} \mathrm{H}\right)$ to label $\mathrm{AFB}_{1}$ and it has been not possible to obtain the amount (in $\mu \mathrm{g} \mathrm{kg}^{-1}$ ) of $\mathrm{AFB}_{1}$ in tissues. Both authors detected $\mathrm{AFB}_{1}$ in several samples (faeces, kidney, gastro-intestinal tract, carcass, urine and bile (Ellis et al. 2000); bile, liver, kidney, brain, abdominal fat, muscle, spleen and blood (Ngethe et al. 1992); liver and brain (Ngethe et al. 1993)) up to six (Ngethe et al. 1993), seven (Ellis et al. 2000) and eight (Ngethe et al. 1992) days after ingestion of AF. ElSayed and Khalil (2009), after feeding seabass with $18 \mu \mathrm{gg}^{-1}$ of $\mathrm{AFB}_{1}$, detected $4.25 \pm 0.85$ $\mu \mathrm{g} \mathrm{AFB}_{1} \mathrm{~kg}^{-1}$ in muscle samples, which correspond to a TF of 0.278 , which is higher than that observed for livestock meat (Table S1). Reported values in muscle in this study $(4.25 \pm 0.85$ $\mu \mathrm{g} A \mathrm{FB}_{1} \mathrm{~kg}^{-1}$ ) are considerably high if one considers that the regulatory limit for $\mathrm{AFB}_{1}$ in human foods set by the US Food and Drug administration is $5 \mu \mathrm{g} \mathrm{kg}^{-1}$. Also, in walleye fish (Sander vitreus), Hussain et al. (1993) reported high levels of $\mathrm{AFB}_{1}, \mathrm{AFB}_{2}, \mathrm{AFG}_{1}$ and $\mathrm{AFG}_{2}$ in muscle, which generated TF of 0.1 to 0.5 , which are comparable to what is obtained for edible offal and higher than that observed for livestock meat (Table S1). In the case of the Hybrid sturgeon (Acipenser ruthenusx A. baeri), animals fed with $40 \mu \mathrm{g} \mathrm{AF} \mathrm{kg-1}$ feed, showed values of $28 \mu \mathrm{g} \mathrm{kg}^{-1}$ of $\mathrm{AF}$ in muscle and $142.80 \mathrm{\mu g} \mathrm{kg}^{-1}$ in the liver (TF $=0.7$ and 3.57) (Raghavan et al., 2011) while when fed with $80 \mathrm{\mu g} \mathrm{kg}^{-1} \mathrm{AF}$ the TF were lower both in muscle and liver ( $\mathrm{TF}=0.4$ and 1.15$)$.

Tropical species have been particularly studied covering both Asian and South American species. Regarding Nile tilapia (Oreochromis niloticus) eight studies have been published to date (Abdel Rahman et al. 2017; Ayyat et al. 2013; Deng et al. 2010; Hessein et al. 2014; Hussain et al. 2017; Mahfouz and Sherif, 2015, Salem et al., 2009; Selim et al. 2014). All studies detected bioaccumulation of AF in muscle and the liver (Table 2). However, these studies vary in terms of fed mycotoxin levels as well as tilapia development stages. Mahfouz and Sherif (2015), used tilapias with an initial weight of $35 \pm 0.50 \mathrm{~g}$, and fed them with 20 or $100 \mu \mathrm{gg}^{-1}$ AF for 12 weeks, with intermediary sampling at six weeks (Table 2). This study 
438 found that both AF levels led to accumulation in the liver and muscle, however, in the liver, 439 AFs were found earlier (six weeks post-intake) than in the muscle (only after 12 weeks). The intake period is an important factor to take into consideration as shown by Mahfouz and Sherif (2015), and equally important would be to establish suitable depuration periods for the different mycotoxins. If feasible, adequate fasting periods before harvesting which currently vary from species to species could be set according to mycotoxin tissue levels. Despite using a considerably high range of $\mathrm{AFB}_{1}$ levels in his study, Deng et al. (2010) observed during a 20 week trial, that even relatively low $\mathrm{AFB}_{1}$ levels $\left(85 \mu \mathrm{g} \mathrm{kg}^{-1}\right)$ could lead to a significantly high accumulation of $\mathrm{AFB}_{1}$ in the liver after 20 weeks of ingestion $\left(\mathrm{AFB}_{1}\right.$ in the liver after 20 weeks $=30 \mu \mathrm{g} \mathrm{kg}^{-1}$; Table 2). In short exposure periods to AF (30 days), Abdel Rahman et al. (2017) observed that the intake of $200 \mu \mathrm{g} \mathrm{kg}^{-1}$ of AF accumulated in the liver and muscle at $5 \pm 0.5$ and $3.7 \pm 0.1 \mu \mathrm{kg}^{-1}$, respectively. This might suggest a certain incapability to metabolize AF.

Other studies also performed in tilapia (Oreochromis niloticus) (Ayyat et al. 2013; Salem et al. 2009; Selim et al., 2014), support the previously reported studies, but show a tendency for a higher accumulation of AFs in muscle (Table 2), which could be related to the smaller size of the tilapias used (7 to 15 grams). For example, Selim et al. (2014) reported the deposition of $90 \mu \mathrm{gg}^{-1}$ of AFs in the muscle after feeding tilapia (15 $\pm 2 \mathrm{~g}$ ) with $200 \mu \mathrm{g} \mathrm{kg}^{-1}$ of AF for ten weeks. Likewise, the Ayyat et al. (2013) and Salem et al. (2009) studies that used fish with an initial weight of $7.3 \mathrm{~g}$ and $10 \mathrm{~g}$, respectively, also showed high values of AFs in the muscle (78.33 $\mathrm{g} \mathrm{kg} \mathrm{k}^{-1}$ and $99.48 \mu \mathrm{g} \mathrm{kg}^{-1}$, respectively). In comparison, in the study by Mahfouz and Sherif (2015) that used fish with an initial weight of $35 \mathrm{~g}$, intake of $100 \mu \mathrm{gg}^{-1}$ AF over 12 weeks led to a lower accumulation of AF in the muscle $\left(0.05 \mu \mathrm{gg}^{-1}\right)$. This tendency for higher AF deposition in younger animals seems to be further confirmed by Hessein et al. (2014), where after feeding tilapias of 7.3 grams for 98 days with $250 \mu \mathrm{gg}^{-1}$ $\mathrm{AF}$, an AF deposition of $101.7 \mu \mathrm{g} \mathrm{kg}{ }^{-1}$ was found. This means a TF of 0.407 that, together with data reported by previous authors (Salem et al. 2009, Selim et al. 2014), have relatively high TFs for muscle and are only comparable to livestock edible offal (Table S1).

Finally, Hussain et al. (2017) showed a high deposition of AF in tilapia muscle, however, the levels of mycotoxins used in this trial (2000 to $4000 \mu \mathrm{g} \mathrm{kg}^{-1}$ ) are unlikely to be found in aquafeeds although TFs calculated for AF deposition in the liver are in line with the other studies. The only trial with red tilapia (Oreochromis niloticus $x$ O. mossambicus), (Usanno et 
al. 2005) reported no detectable levels of AF in tilapia tissues, after being fed AF levels 471 ranging from 50 to $2500 \mu \mathrm{gg}^{-1}$.

472 The deposition of AFs in the liver and muscle of Gibel carp (Carassius gibelio) are similar to 473 the levels reported for Nile tilapia (Huang et al. 2011).

474 Lopes et al. (2009) reported the deposition of AFs in the liver and muscle in Jundiá (Rhamdia quelen) fed low (41.90 and $204 \mu \mathrm{g} \mathrm{kg}^{-1}$ ) and high (350, 757 and $1177 \mu \mathrm{g} \mathrm{kg}^{-1}$ ) AF levels for 45 and 35 days, respectively. Focusing on lower AF levels, as they are whithin the observed AF's occurrence levels in aquafeeds, $41.90 \mu \mathrm{gF} \mathrm{kg}^{-1}$ feed led to the deposition of $1 \mu \mathrm{g} \mathrm{kg}^{-1}$ in the muscle and $204 \mu \mathrm{g} \mathrm{kg}-1$ of AFs led to the deposition of $6.1 \mu \mathrm{g} \mathrm{kg}{ }^{-1}$ AFs. These bioaccumulation level of AFs leads to TFs of 0.02 , which is comparable to the level of accumulation on livestock edible offal's ((Leeman et al. 2007); Table S1) Lambari fish (Astyanax altiparanae), a native central/south American small fish $(10-15 \mathrm{~cm}$ length and $60 \mathrm{~g}$ ), has been seen as a potential aquaculture species for rural population in Brasil. Michelin et al. (2017) reported lambari fish as highly prone to AF deposition in the 484 liver and muscle. After lambari fish were fed $20 \mathrm{~kg}^{-1}$ of AFs for 120 days, deposition of AFs in the liver was $265 \mathrm{\mu g} \mathrm{kg}^{-1}$ (TF 13.5) and in fish fed $50 \mu \mathrm{g} \mathrm{kg}^{-1} \mathrm{AFs}$ levels in the liver were 243 $\mu \mathrm{gg}^{-1}$ (TF 4.86). This level of bio-accumulation in the liver is higher than the bioaccumulation of highly liposoluble mycotoxins in terrestrial animal fat ((Leeman et al. 2007); Table S1). Such AFs levels in this species could be particularly challenging as these fish are normally eaten as snacks, i.e., the entire fish is deep-fried, dried and/ or salted. Reports of AF carry-over in shrimp are limited to three studies performed in black tiger shrimp (Penaeus monodon). Two of these studies (Bintvihok et al. 2003; Bautista et al. 1994) did not find any AF residues after feeding shrimps with different AF concentrations (5 to 200 $\mu \mathrm{g} \mathrm{kg}^{-1}$ ) for 10 and 62 days, respectively. In contrast, Boonyaratpalin et al. (2001) found AF residues in cephalothorax and in muscle, after feeding the shrimps $A F B_{1}$ levels ranging from 50 to $2500 \mu \mathrm{g} \mathrm{kg}^{-1}$ with TF values ranging from 0.006 to 0.052 . Contextualizing the AF contamination levels found in feed around SE Asia (<500 $\mathrm{g} \mathrm{kg}^{-1}$; (Fegan and Spring, 2007; Gonçalves et al. 2018a; Gonçalves et al. 2018; Gonçalves et al. 2017)) with the Boonyaratpalin et al. (2001) study, shrimps fed $\mathrm{AFB}_{1}$ levels of 50 and $100 \mu \mathrm{g} \mathrm{kg}^{-1}$ led to considerably high AF deposition in head and shell (2.6 and $3.5 \mu \mathrm{g} \mathrm{kg}^{-1} \mathrm{AFB}_{1}$, respectively) and 500 in muscle (13 and $14.2 \mu \mathrm{g} \mathrm{kg}^{-1} \mathrm{AFB}_{1}$, respectively), after four weeks of $\mathrm{AFB}_{1}$ intake. For the 501 same intake amounts (50 and $100 \mu \mathrm{g} \mathrm{kg}^{-1} \mathrm{AFB}_{1}$ ), $\mathrm{AFB}_{1}$ deposition levels in head/shell and 
502

503

504

505

506

507

508

509

510

511

512

513

514

515

516

517

518

519

520

521

522

523

524

525

526

527

528

529

530

531

532

muscle samples decreased over time (after six weeks; Table 2). This might suggest a certain capacity to eliminate or metabolize $\mathrm{AFB}_{1}$.

\section{Ochratoxins (OTA)}

Ochratoxin bioaccumulation studies in aquaculture-farmed species are very scarce. The most comprehensive study was carried out by Bernhoft et al. (2017) in Atlantic salmon (Salmo salar). Bernhoft et al. (2017) studied the deposition of OTA in liver, muscle, kidney and skin samples after feeding salmon with 800 or $2400 \mu \mathrm{gg}^{-1}$ of OTA for eight weeks. Deposition of OTA in kidney and skin samples was not detected (except in kidney for high intake dosage after eight weeks, Table 3). In muscle samples, OTA levels were under the limit of quantification. Major deposition was observed in the liver, however, a bioaccumulation over the exposure period was not found, with the highest OTA deposition peaking after three weeks (both for ingestion of 800 and $2400 \mu \mathrm{kg}^{-1}$ OTA). This suggests that Atlantic salmon might have the ability to eliminate OTA. Previously, OTA deposition in salmonids (rainbow trout (Oncorhynchus mykiss)) was investigated by Fuchs et al. (1986) where the deposition of OTA in several organs (Table 3) was analysed up to eight weeks after an intravenous injection of OTA $\left(0.160 \mu \mathrm{g} \mathrm{kg}^{-1}\right)$. Authors observed that OTA deposition in the kidney and bile was persistent during the whole trial, also suggesting the action of the kidney in detoxification mechanism of OTA. The only study reporting carry-over of OTA in shrimp (Penaeus monodon) was by Supamattaya et al. (2005a), which did not detect OTA deposition in tissues after feeding shrimps with OTA levels ranging from 100 to $1000 \mu \mathrm{gg}^{-1}$. However, the limit of detection given in the manuscript $\left(44,000 \mu \mathrm{g} \mathrm{kg}^{-1}\right)$ seems to be particularly high for HPLC, suggesting a possible error in the units reported.

\section{Deoxynivalenol (DON) and fumonisins (FUM)}

Deoxynivalenol and/or FUM bioaccumulation data in aquaculture species is summarized in Table 4. Similar to OTA, DON and FUM carry-over effects in aquaculture-farmed are scarce. In Atlantic salmon (Salmo salar), two studies are available (Bernhoft et al. 2017 and NácherMestre et al. 2015). Bernhoft et al. (2017) fed salmon with 2000 and $6000 \mu \mathrm{g} \mathrm{kg}^{-1}$ DON over the course of eight weeks and sampling liver, muscle, kidney and skin at three, six and eight weeks. The authors observed that both exposure dosages (2000 and $6000 \mu \mathrm{gg}^{-1} \mathrm{DON}$ ) led 
533 to DON deposition in the liver and muscle at all sampling points, except for the higher dosage at the last sampling point (eight weeks), at which DON was found in all sampled tissues (Table 4). In the case of the study performed by Nácher-Mestre et al. (2015), Atlantic salmon were fed lower levels of mycotoxins, however, with multi-occurrence. The three diets were mainly formulated with DON and FUM, but also minor levels of T-2 and 15AcDON (Table 4). Salmon fed for six months with testing diets did not show detectable levels of DON and FUM in the tissues studied. The same authors (Nácher-Mestre et al. 2015) also studied bioaccumulation of mycotoxin co-occurrence (DON, 15-AcDON and FUM) in Gilthead sea bream (Sparus aurata) at two levels for 8 months. The authors did not observe mycotoxin deposition in muscle samples.

In common carp (Cyprinus carpio), Pietsch et al. (2014) observed that after feeding fish with 352, 619 and $953 \mu \mathrm{g} \mathrm{kg}^{-1}$ DON for four weeks, minor deposition of DON was observed in the muscle (Table 4). Interestingly, after the four weeks of DON exposure, fish were fed a noncontaminated diet for a period of two weeks and DON levels in the muscle were re-analysed. At the lower DON intake level $\left(352 \mu \mathrm{gg}^{-1}\right)$, DON level in the muscle was higher after the depuration period (1.4 $\mu \mathrm{g} \mathrm{kg}^{-1}$ ) when compared to the level found at the end of feeding trial (eight weeks; $0.6 \mu \mathrm{g} \mathrm{kg}{ }^{-1}$ DON). At the medium DON intake level (619 $\mu \mathrm{g} \mathrm{kg}^{-1}$ ), after the recovery period, a level of $0.7 \mu \mathrm{g} \mathrm{kg}^{-1} \mathrm{DON}$ was still found in the muscle, and at the higher level, however, no DON was detected after the recovery period.

In shrimps, two studies are available (Supamattaya et al. 2005b and Trigo-Stockli et al. 2000) Table 4), in which both reported that DON was not detected in the muscle. Supamattaya et al. (2005b) drew its conclusion after feeding black tiger shrimp black (Penaeus monodon) with 500, 1000 and $2000 \mu \mathrm{g} \mathrm{kg}^{-1}$ DON for eight weeks. Trigo-Stockli et al. (2000) conducted its study using Pacific white shrimp (Litopenaeus vannamei), fed with 200, 500 and $1000 \mu \mathrm{g}$ $\mathrm{kg}^{-1}$ DON for 16 weeks.

\section{Zeralenone (ZEN)}

Zearalenone (ZEN) is a regular contaminant of cereal crops worldwide, and being a phytoestrogenic compound (Diekman and Green, 1992), is mainly responsible for estrogenic agonist related effects (Marasas, 1991). As a hormone mimicking substance, ZEN can bind to estrogen receptors in target cells (Kumar et al., 2013). Generally, ZEN studies 
565 have focused mainly on dysfunction or structural disorders in the reproductive tract of farm 566 animals (Minervini and Aquila, 2008; Zinedine et al. 2007; Woźny et al. 2013). While it seems 567 that ZEN does not directly affect the growth performance of aquaculture-farmed species, its 568 deposition in fish tissues seems to be common and already well documented particularly in 569 cold water species (Pietsch et al. 2015; Woźny et al. 2015; Arukwe et al. 1999; Woźny et al. 2017).

571 In common Carp (Cyprinus carpio), Pietsch et al. (2015) found that after exposing fish to four 572 weeks with 332, 621 and $797 \mu$ ZEN kg $^{-1}$ feed, minor residues of ZEN and $\alpha$-ZEN were found 573 in the muscle. Interestingly, after two weeks of depuration, $\alpha$-ZEN was not detected and ZEN 574 levels in the muscle decreased significantly (Table 5).

575 Woźny et al. $(2015 ; 2017)$ dedicated significant efforts at understanding the potential of ZEN 576 bioaccumulation in fish, using mainly rainbow trout as a model. The authors found that after 577 feeding rainbow trout with $1,810 \mu \mathrm{g}$ ZEN kg${ }^{-1}$ feed for 71 days, ZEN was found at a 578 concentration of $732.2 \mu \mathrm{g} \mathrm{kg}^{-1}$ in the intestine while non-quantifiable levels of ZEN were 579 found in liver and female ovaries. In another trial, Woźny et al. (2017) used mature females $580(1,274 \pm 162 \mathrm{~g})$ to study ZEN carry-over into eggs. Authors found that ZEN is transferred from 581 the gastrointestinal tract to the reproductive system of the fish, depositing ZEN metabolites 582 in the somatic cells of the ovaries rather than in the oocytes.

583

584 585 586 587

Discussion on the carry-over data obtained from feeding trials

In order to take realistic conclusions regarding the risk of mycotoxin consumption from aquaculture seafood products, it is necessary to have a good overview of mycotoxin occurrence in aquaculture feeds, and to have quality data on mycotoxin bioaccumulation in aquatic species.

From all the studies regarding AF carry-over presented in Table 2, a few of them should be excluded due to the use of high levels of AFs (Hussain et al. 2017); or higher dosages, which are not normally observed in commercial feeds (Deng et al.,(2010), Boonyaratpalin et al. (2001) and Usanno et al. (2005)). The studies reported by the remaining authors, employed plausible dietary mycotoxin levels, identifying the carry-over of AFs in several important species. 
596 From these studies, it is possible to conclude that AFs might represent a serious risk for human consumption, especially in cases where fish are eaten as a whole. In general, transfer factors are quite high for these aquaculture species, being comparable with transfer factors for eggs, whole milk and in some cases for edible offal's or fat of livestock provenience. In the case of European seabass, mycotoxin levels tested by El-Sayed and Khalil (2009) (18 $\mu \mathrm{g}$ $\left.\mathrm{kg}^{-1}\right)$, which is a mycotoxin level very plausible to be obtained in commercial diets led to 4.25 $\pm 0.85 \mu \mathrm{g} \mathrm{AFB}{ }_{1} \mathrm{~kg}^{-1}$ in the muscle,. As shown by Altuğ and Berklevik (2001) (Table 1), of the 170 samples collected in Turkey, which is the main EU seabass producer, 105 samples were contaminated with AFs at levels higher than $20 \mu \mathrm{gg}^{-1}$. Regarding hybrid sturgeon (Acipenser ruthenus), there is no available mycotoxin occurrence data for this species, even in regions where it is predominantly produced. However, in-feed concentrations tested by Rajeev Raghavan et al. (2011), which led to the accumulation of AF in the muscle and liver, seem realistic (40 to $80 \mu \mathrm{g} A F B 1 \mathrm{~kg}^{-1}$ ) and therefore further research should be carried out to determine mycotoxin levels in feed for this species and AF accumulation in eggs (caviar). Carry-over effects on Nile tilapia are well described. Taking into account the available occurrence of AF in tilapia producing countries, i.e., Brasil (Barbosa et al. 2013), S/ SE Asian countries (Fegan and Spring, 2007; Gonçalves et al. 2018a; Gonçalves et al. 2018; Gonçalves et al. 2017) and Africa (Marijani et al. 2017) together with bioaccumulation studies, carryover of AF in Nile tilapia might represent a challenge worth of further investigation. From the previously cited studies, it is also important to highlight that exposure period is an important factor to take into consideration. Chronic exposure to low AF levels (AF $=85 \mu \mathrm{g}$ $\mathrm{kg}^{-1}$ for 20 weeks) could lead to a significantly high accumulation in the liver (AF in the liver after 20 weeks $=30 \mu \mathrm{kg}^{-1}$ (Deng et al. 2010)). However, short exposure periods should not be undervalued, as periods as short as 30 days can lead to considerable AF deposition in the liver and muscle (Abdel Rahman et al. 2017). Aflatoxin carry-over studies in shrimp are more limited than in fish species. Furthermore, the information available is contradictory, as two studies (Bintvihok et al. 2003 and Bautista et al. 1994) did not find any AF residues in tiger shrimp muscle while Boonyaratpalin et al. (2001) found AF bioaccumulation in head/shell and in the muscle. Results suggested a minor bioaccumulation over time (TFs; Table 2), highlighting a certain capacity to eliminate or metabolize $A F B_{1}$. However, levels of $A F$ found in the muscle (13 $\mu \mathrm{g} \mathrm{kg}^{-1} A F B_{1}$ ) after feeding shrimps $50 \mu \mathrm{g} \mathrm{kg}^{-1}$ of $\mathrm{AFB}_{1}$ for four weeks were considerably high and could be a threat for 
628 human food safety. AF deposition, especially in head samples, should not be undervalued. In 629 many countries, heads are used for direct human consumption. Unfortunately, no 630 information is available for Pacific white leg shrimp (Litopenaeus vannamei) which is the 631 most important produced shrimp species in terms of volume.

632 For OTA occurrence, little information is available for aquaculture feeds, however, according 633 to available studies, levels below $10 \mu \mathrm{g} \mathrm{kg}^{-1}$ have been reported (Fegan and Spring, 2007; 634 Gonçalves et al. 2018a; Gonçalves et al. 2018; Gonçalves et al. 2017; Greco et al. 2015). The risk of OTA carry-over was only successfully addressed in Atlantic salmon and partially in rainbow trout. In Atlantic salmon (Bernhoft et al. 2017), it would appears that OTA is rapidly eliminated. Its deposition in tissues was only shown in liver $\left(4.81 \mathrm{\mu g} \mathrm{kg}^{-1}\right)$ and only at the highest OTA intake level $\left(2400 \mu \mathrm{g} \mathrm{kg}^{-1}\right)$. These OTA levels are unlikely to be observed in commercial feeds. In rainbow trout, OTA deposition in the muscle was not detected after $24 \mathrm{~h}$ of OTA intake. This again suggests a rapid elimination of OTA and decreases the risk for human consumption as fasting periods before slaughter in salmonids are normally longer than 24 hours. However, it is highly recommended that more studies are undertaken on OTA carry-over, especially for species were OTA occurrence in feeds is more frequent and higher, such as tropical species, where fasting periods before harvest also tend to be much shorter than for cold-water species and also tropical crustacean species. DON, FUM and ZEN occurrence in aquafeeds have been well documented in recent years (Pietsch et al. 2013; Nácher-Mestre et al. 2015; Gonçalves et al. 2018a; Gonçalves et al. 2018; Gonçalves et al. 2017; Greco et al. 2015; Marijani et al. 2017). These mycotoxins have been pointed out as the main mycotoxin contaminants in aquaculture feeds, which is a reflection of the increasing inclusion levels of plant meals in diets, as these mycotoxins are produced in field conditions. However, DON and FUM bioaccumulation has been poorly studied in aquaculture-farmed species. In Atlantic salmon, two interesting and complementary studies are available (Bernhoft et al., 2017 and Nácher-Mestre et al., 2015). While Bernhoft et al. (2017) proved the possibility of DON deposition in the liver and muscle in a relatively short exposure period (three weeks) with high DON levels (2000 and $6000 \mu \mathrm{g}$ $\mathrm{kg}^{-1}$ DON), Nácher-Mestre et al. (2015) showed no carry over effects of FUM and DON cocontamination at low levels during long exposure periods. DON and FUM frequently occur together in aquaculture feeds as both mycotoxins are produced by the same fungi species. 
660

661

662

663

664

665

666

667

668

669

670

671

672

673

674

675

676

677

678

679

680

681

682

683

684

685

686

687

688

689

690

tested were within the occurrence values reported in European aquafeeds (Gonçalves et al. 2017; Gonçalves et al. 2018), however, occasional high occurrences of DON and/or FUM should not be ignored (e.g., FUM occurrence reported by Gonçalves et al. (2018)), as shown previously, levels up to $2000 \mu \mathrm{g} \mathrm{kg}^{-1}$ can lead to DON deposition in the muscle.

Contrary to Atlantic salmon, in common carp (Cyprinus carpio), Pietsch et al. (2014) showed that levels as low as $352 \mu \mathrm{g} \mathrm{kg}^{-1}$ DON can lead to a minor deposition of DON in the muscle (Table 4). The author described that total DON elimination from the muscle is a relatively long process, taking more than two weeks after stopping DON intake. Information about the complete elimination of DON is very important, as a fasting period before harvesting may be used to guarantee that DON or any other mycotoxin is eliminated during this period. However, in the study reported by Pietsch et al. (2014), the elimination period of DON in carp may be longer than the fasting period, which is normally 24 to 48 hours before harvesting. The study by Pietsch et al. (2014) highlighted that mycotoxin absorption, distribution, metabolism, and excretion (ADME) is entirely dependent on species, and data or conclusion extrapolations between species should be avoided. Fusarium mycotoxins (e.g., DON and FUM) are frequently present in plant commodities used for general aquaculture species, and taking into account the possible ADME differences depending on species and even on development stages, it would be very important to better understand the potential carry-over in the most important aquaculture species, giving a special emphasis to mycotoxin co-occurrence.

Despite the low number of studies on DON and FUM carry-over, apparently, its deposition in tissues seems to be very limited. However, its occurrence is frequent and due to its apparently long elimination period (generally higher than fasting period before slaughter, for the study species), its carry-over risk in aquaculture-farmed species should be better evaluated. Comparing TFs obtained from Atlantic salmon and common carp, it seems that they are in line with the TFs of eggs, whole milk or meat (Table S1, (Leeman et al. 2007)). Is also important to highlight that the species investigated so far are cold/temperate water species. It is essential to increase the knowledge on the possible carry-over of Fusarium spp. mycotoxins in tropical species. Especially high value species, normally exported, such as Pacific white leg shrimp, whose feeds have been identified recently as being contaminated with considerably high levels of DON (Gonçalves et al. 2018a). Furthermore, these tropical 
691 species present a faster metabolism and consequently lower fasting period before harvest is

692

693

694

695

696

697

698

699

700

701

702

703

704

705

706

707

708

709

710

711

712

713

714

715

716

717

718

719

720

721

722 need, which might greatly influence the deposition of mycotoxins in tissues.

From the few available studies evaluating ZEN carry-over effects, it is possible to conclude that, at least for the cold-water species studied so far (common carp and rainbow trout), ZEN and its metabolites can be deposited in several tissues, including muscle, intestine, liver, ovaries and oocytes. However, the levels found in these tissues, with the exception of the intestine and liver (Table 5, (Woźny et al. 2017)), are rather low and do not pose a direct risk to human consumption. In the European Union, the maximum allowable level of ZEN ranges from $20 \mu \mathrm{gg}^{-1}$ for processed cereal-based foods (excluding processed maize-based foods) and baby foods for infants and young, to $300 \mu \mathrm{g} \mathrm{kg}^{-1}$ for unprocessed maize (not for human consumption) (EC, 2006). However, European legislation does not include limits for the concentration of ZEN residuals in food of animal origin, since it is thought that carry-over of the Fusarium mycotoxins (including DON and FUM previously discussed) to meat, milk and eggs is only minimal (CONTAM, 2011; EC, 2006).

Moreover, ZEN and its metabolites seem to be more easily deposited in the somatic cells of the ovaries rather than in the oocytes. For rainbow trout and common carp, tissues such as ovaries, liver and intestines are not typically edible, however, for other species this might not be the case. It would be very important to assess the carry-over of ZEN and its metabolites for other aquaculture-farmed species, taking into account what is already known in rainbow trout and common carp. It is particularly interesting to evaluate species that reach sexual maturation before or near harvesting size. ZEN in feed may accelerate the sexual maturation of the fish, leading to energy losses to gonad development, and in some cases organoleptic and physical changes of the final product. For some species, ZEN in feed may also have potential implications for fish and shrimp spawning and further studies need to address this topic. In addition, fish/shrimp species that might be consumed entire, i.e., including tissues such as the liver, intestines and ovaries should be taken into consideration, as ZEN might reach considerably high levels in these tissues. In certain cases, the use of fish/shrimp by-products in direct human consumption (fish oil) or as an ingredient to formulate new products, should also be taken into consideration as Fusarium mycotoxins tend to be quite stable to processing conditions and only minor degradation is expected 
723 Table 6 documents mycotoxin occurrence in commercially sourced aquaculture products.

724 Evaluating the occurrence of mycotoxins directly in fish/shrimp products from aquaculture 725 provenience obtained from commercial farms or local supermarkets is a good strategy to 726 evaluate the potential risk of mycotoxin carry-over from feeds to fish/shrimp edible products. Tolosa et al. (2013) analysed several samples $(n=19)$ of fish from aquaculture and wild fishery provenience bought locally in Spain. The author analysed samples for the presence of beauvericin (BEA) and enniatins (enniatin A (ENA), enniatin A1 (ENA1), enniatin B (ENB) and enniatin B1 (ENB1)). As expected, no mycotoxins were detected in the wild fishery samples. ENA and BEA were also not detected in the aquaculture samples. However, ENA1, ENB and ENB1 were detected in most of aquaculture samples (Table 6). Detecting enniatins in aquaculture foods might lead us to two hypothesis. First, that other Fusarium mycotoxins (FUM, DON and ZEN mainly) were probably at even higher concentration levels and are not reported as they were not analysed. The second hypothesis is the fact that ENNs might be more easily deposited in the muscle compared to DON/FUM, even if present at lower levels in aquafeeds. As it is known that ENNs normally occur together with the main Fusarium mycotoxins (FUM, DON), it would also be important to study if this synergistic presence in the tissues might lead to increased deposition of certain mycotoxins or metabolites. While it is difficult to evaluate the importance of detecting ENNS in aquaculture foods, these results highlight the need to better study the adverse effects of dietary mycotoxins on fish health and welfare, and consequently carry-over risks. There is the need to perform studies for the main EU farmed fish species in order to establish acceptable feed mycotoxin levels for farmed fish (for both fish and consumer safety), but also to actively survey possible mycotoxin deposition in imported aquaculture foods. Woźny et al. (2013) analysed ZEN in rainbow trout from farms based in the north-eastern region of Poland. ZEN was present at non-quantifiable levels $\left(<2.0 \mu \mathrm{g} \mathrm{kg}^{-1}\right)$ in most of the tissues analysed (intestine, liver and ovary) and detectable at quantifiable levels in the muscle and surrounding water. From 2013 to 2015, Woźny et al. (2017) surveyed ovary, oocytes and salted roe samples from different fish species collected directly at hatcheries or bought in supermarkets. The authors analysed the samples for the presence of ZEN, $\alpha$-ZEL and $\beta$-ZEL. Generally, in most of the samples analysed mycotoxins were below the detection 753 limits (LOD for ZEN, $\alpha$-ZEL, and $\beta$-ZEL were 5.0, 3.0, and $12.0 \mu \mathrm{g} \mathrm{kg}^{-1}$, respectively). The 754 exceptions were $\alpha$-ZEL in ovary samples $\left(14.5 \mu \mathrm{g} \mathrm{kg}^{-1}\right)$ of Oncorhynchus mykiss and $\alpha$-ZENL 
755 also in ovary samples $\left(12.6 \mu \mathrm{g} \mathrm{kg}^{-1}\right)$ of Salvelinus fontinalis both sampled in 2014 . The studies reported by Woźny et al. $(2013 ; 2017)$ are also extremely important and highlight the need for guidance values for the amount of ZEN in aquafeeds for fish health and reproductive performance, but also to avoid carry-over risk to human consumers. Although it did not investigate fish originating from aquaculture, it is important to highlight the recent study published by Slawomir Gonkowski et al., (In Press). Slawomir Gonkowski et al., (In Press) evaluated the deposition of ZEN in sun-dried kapenta fish, which is one of Zambia's major staple foods. This small planktivorous fish is caught in Lake Kariba, sun-dried and sold in local markets. Although the source of the ZEN deposition is not known, the study revealed that levels of ZEN in sun-dried kapenta fish fluctuated from about $27 \mu \mathrm{gg}^{-1}$ to above $53 \mu \mathrm{g} \mathrm{kg}^{-1}$. Occurrence of ZEN in sun dried kapenta fish, highlights that carry-over guidelines cannot be assumed only for farmed animals as species and local consumption habits pose mycotoxin-related risks to wider seafood products.

\section{Further considerations}

Despite the effort to document mycotoxin occurrence in aquaculture feeds, we are still far from having a good overview on this topic. One of the big challenges is the large number of aquaculture-farmed species, and the impossibility to extrapolate occurrence results from one species to another. Moreover, different species, even in same trophic level, tend to be fed with different raw materials based on local availability and price. This leads to a huge difficultly in having a good overview of mycotoxin occurrence for all aquaculture species or even for a certain region. Nevertheless, knowledge about mycotoxin occurrence in aquaculture commodities could increase significantly if we could better use the available occurrence data from livestock. Surveys on mycotoxin occurrence in plant meals worldwide are frequently available, and this information can be used, at least, to theoretically model the risk of plant feedstuffs included in aquafeeds. However, a fundamental problem is the lack of detailed labelling information regarding ingredient inclusion by (percentage) weight. Therefore, an improvement in labelling policy would help to identify and map sources of mycotoxin inclusion in animal feed, avoiding extra costs for testing mycotoxin levels in finished feeds. Therefore, a close collaboration with the agricultural and livestock sectors to understand the occurrence of mycotoxins in plant meals, might also help to improve our knowledge on mycotoxin conveyance to aquafeeds. 
787 Mycotoxins conveyed from land animals and aquaculture by-products cannot be despised, especially in countries were mycotoxin occurrence might be poorly legislated. The identification of mycotoxins in shrimp head meal or chicken droppings highlights the possible bio-amplification through the food chain.

To our knowledge not yet addressed in an aquaculture context, is the potential for mycotoxins to contaminate water, especially taking into account water stable mycotoxins and closed or semi-closed aquaculture systems. Bucheli et al. (2008) evaluated the presence of ZEN and DON in Swiss rivers, confirming the presence of both mycotoxins at levels ranging from $23 \mathrm{ng} \mathrm{L}{ }^{-1}$ to $4.9 \mathrm{\mu g} \mathrm{L}^{-1}$ for DON and $35 \mathrm{ng} \mathrm{L}^{-1}$ for ZEN. Bucheli et al. (2008) highlighted the possibility of mycotoxins as water contaminates, which in the aquaculture context might be extremely relevant. The mycotoxin leach from aquafeed to system water, especially of highly water-soluble mycotoxins in slow feeding species, e.g., DON and FUM in shrimp feed, and the water stability of excreted mycotoxins and metabolites, which might have potential to accumulate, especially in low water hydrodynamics and low renovation rate aquaculture systems, should be urgently addressed.

\section{CONCLUSION}

The available carry-over studies indicate that deposition of mycotoxins into edible tissues may be higher than in terrestrial species and it is therefore imprudent to assume the same transfer factors for aquaculture species as for livestock species. In general, aflatoxins seem to be particularly prone to deposition in several fish and shrimp tissues representing a risk for human consumption, especially in species that are eaten as a whole. Ochratoxin A occurrence in aquafeeds has been described as very low. While its deposition in tissues has been reported for some aquaculture species, its rapid elimination decreases the risk for human consumption as the fasting period before slaughter can be safely used as a depuration period. Nonetheless, it is important to make the industry aware of its possible deposition. Deoxynivalenol and fumonisins are some of the most frequently occurring mycotoxins in feeds, and they are occasionally detected at high levels. So far, for the species described, DON and FUM deposition in tissues seems low. However, DON elimination from the muscle takes a relatively long time, much longer than the depuration/fasting period. The presence of enniatins in aquaculture food products highlights the possibility that other 
819 Fusarium metabolites might be more prone to bioaccumulation than the most common 820 frequently analysed Fusarium mycotoxins. The presence of enniatins in aquaculture foods 821 highlights the need to understand its potential impact to human food safety.

822 Regarding ZEN, the potential for deposition in the ovaries and to a lesser extent in oocytes 823 was shown. For the studied species, ZEN can reach considerable levels in the ovaries. No 824 studies are available yet for tropical species. It would be important to investigate whether 825 carry-over of ZEN to ovaries occurs in tropical species as well, as for many of these species, 826 gonads are considered gourmet snacks, representing a direct risk to human health.

827 While there are many important aquaculture species not investigated yet, it is clear that 828 some mycotoxins are prone to deposition in the tissues of certain aquaculture species. It needs to be considered that in aquaculture species, mycotoxin biotransformation and tendency for deposition in tissues varies greatly depending on factors such as development stage, sex, exposure period and rearing environment.

832 Due to the use of increasing levels of plant meals in aquafeeds and together the possible mycotoxin increase due to climate change, it is essential to develop more studies on the impact of mycotoxins and metabolites on farmed species with consequent risk assessment of food safety from mycotoxin-contaminated aquafeeds. Regulation limits for mycotoxins in feeds might need to take into account particular aquaculture species or the sector as a whole. Mycotoxin limits need to take into consideration animal health and welfare but also human health. Particular attention needs to be focused on aquaculture edible tissues and regional guidance limits should be advised depending on local mycotoxin occurrence and the edible tissues consumed. Risk assessment

841 of imported aquaculture foods needs to take into account the mycotoxin occurrence, especially in those products imported from highly mycotoxin contaminated regions, or regions known to use potentially contaminated animal by-products. 
Abdel Rahman, A. N., Abdellatief, S. A. \& Mahboub, H. H. H. 2017. Protection of Nile tilapia, Oreochromis niloticus from aflatoxin B1 toxicity by dietary supplementation with Fennel essential oil and Saccharomyces cerevisiae. The Egyptian Journal of Aquatic Research, 43, 235-240.

Alinezhad, S., Tolouee, M., Kamalzadeh, A., Motalebi, A. A., Nazeri, M., Yasemi, M., ShamsGhahfarokhi, M., Tolouei, R. \& Razzaghi-Abyaneh, M. 2011. Mycobiota and aflatoxin B1 contamination of rainbow trout (Oncorhinchus mykiss) feed with emphasis to Aspergillus section Flavi. Iranian Journal of Fisheries Sciences, 10, 363-374.

Almeida, I. F. M., Martins, H. M. L., Santos, S. M. O., Freitas, M. S., da Costa, J. M. G. N. \& d'Almeida Bernardo, F. M. 2011. Mycobiota and Aflatoxin B1 in Feed for Farmed Sea Bass (Dicentrarchus labrax). Toxins, 3, 163-171.

Altuğ, G. \& Berklevik, G. 2001. Level of Aflatoxin in Some Fish Feeds from Fish Farming Processes, Feed Factories and Imported Feeds. Turkey Journal Veterinary Animal Science, 27, 1247-1252.

Anater, A., Manyes, L., Meca, G., Ferrer, E., Luciano, F. B., Pimpão, C. T. \& Font, G. 2016. Mycotoxins and their consequences in aquaculture: A review. Aquaculture, 451, 1-10.

Arukwe, A., Grotmol, T., Haugen, T. B., Knudsen, F. R. \& Goksøyr, A. 1999. Fish model for assessing the in vivo estrogenic potency of the mycotoxin zearalenone and its metabolites. Science Total Environment, 236, 153-161.

Ayyat, D. M., A Abd Rhman, G., I El-Marakby, H., Mahmoud, H. \& A A Hessan, A. 2013. Issued by the Egyptian Society of Nutrition and Feeds REDUCTION THE AFLATOXIN TOXICITY IN NILE TILAPIA FISH.

Barbosa, T., Pereyra, C., Soleiro, C., Dias, E., Oliveira, A., Keller, K., Silva, P. P., Cavaglieri, L. \& Rosa, C. A. 2013. Mycobiota and mycotoxins present in finished fish feeds from farms in the Rio de Janeiro State, Brazil. International Aquatic Research, 5, 3.

Bautista, M., Lavilla-Pitogo, C., Subosa, P. \& Begino, E. 1994. Aflatoxin B1 contamination of shrimp feeds and its effect on growth and hepatopancreas and pre-adult Penaeus monodom. Journal Science Food Agriculture, 65, 5 - 11. 
877 Bernhoft, A., Høgåsen, H. R., Rosenlund, G., Ivanova, L., Berntssen, M. H. G., Alexander, J., 878 Eriksen, G. S. \& Fæste, C. K. 2017. Tissue distribution and elimination of

879

880

881

882

883

884

885

886

887

888

889

890

891

892

893

894

895

896

897

898

899

900

901

902

903

904

905

906

907

908 deoxynivalenol and ochratoxin A in dietary-exposed Atlantic salmon (Salmo salar). Food Additives \& Contaminants: Part A, 34, 1211-1224.

Bintvihok, A., Ponpornpisit, A., Tangtrongpiros, J., Panichkriangkrai, W., Rattanapanee, R., Doi, K. \& Kumagai, S. 2003. Aflatoxin contamination in shrimp feed and effects of aflatoxin addition to feed on shrimp production. Journal Food Protein, 66, 882-885.

Boonyaratpalin, M., Supamattaya, K., Verakunpiriya, V. \& Suprasert, D. 2001. Effects of aflatoxin B1 on growth performance, blood components, immune function and histopathological changes in black tiger shrimp (Penaeus monodon Fabricius). Aquaculture Research, 32 388-398.

Bucheli, T. D., Wettstein, F. E., Hartmann, N., Erbs, M., Vogelgsang, S., Forrer, H. R. \& Schwarzenbach, R. P. 2008. Fusarium mycotoxins: overlooked aquatic micropollutants? Journal Agricculture Food Chemistry, 56, 1029-1034.

CAST 2003. Mycotoxins: risks in plant, animal and human systems. in C. f. A. S. a. Technology editor. Task Force Report. Ames, IA.

Cheli, F., Pinotti, L., Rossi, L. \& Dell'Orto, V. 2013. Effect of milling procedures on mycotoxin distribution in wheat fractions: A review. LWT - Food Science and Technology, 54, 307-314.

CONTAM 2011. (European Food Safety Authority Panel on Contaminants in the FoodChain). Scientific Opinion on the risks for public health related to the presence of zearalenone in food. EFSA Journal, 9, 2197.

Davis, D. A. \& Sookying, D. 2009. Strategies for reducing and/or replacing fishmeal in production diets for the Pacific white shrimp, Litopenaeus vannamei. Pages 108-114 in e. C.L. Browdy \& D.E. Jory editor. The Rising Tide, Proceedings of the Special Session on Sustainable Shrimp Farming. World Aquaculture 2009, Baton Rouge, USA, World Aquaculture Society.

Deng, S.-X., Tian, L.-X., Liu, F.-J., Jin, S.-J., Liang, G.-Y., Yang, H.-J., Du, Z.-Y. \& Liu, Y.-J. 2010. Toxic effects and residue of aflatoxin B1 in tilapia (Oreochromis niloticus $\times 0$. aureus) during long-term dietary exposure. Aquaculture, 307, 233-240.

Diekman, M. A. \& Green, M. L. 1992. Mycotoxins and reproduction in domestic livestock. Journal Animal Science, 70, 1615-1627. 
Domenico Caruso, Pascale Talamond \& Moreau., Y. 2013. Mycotoxins and fish farming: A risk left behind? Cahiers Agricultures, 22, 165-173.

EC 2006. Commission Recommendation No 2006/576 of 17 August 2006 on the presence of deoxynivalenol, zearalenone, ochratoxin A, T-2 and HT-2 and fumonisins in products intended for animal feeding. Off. J. Eur. Union, 7-9.

EFSA 2004a. Opinion of the Scientific Panel on Contaminants in Food Chain on a request from the Commission related to ochratoxin A (OTA) as undesirable substance in animal feed Request No EFSA-Q-2003-039 Adopted on 22September 2004. EFSA Journal, 101, 1-36.

EFSA 2004b. Opinion of the Scientific Panel on contaminants in the food chain [CONTAM] related to Aflatoxin B1 as undesirable substance in animal feed. EFSA Journal, 2, 39.

EFSA 2004c. Opinion of the Scientific Panel on Contaminants in the Food Chain on a request from the Commission related to Deoxynivalenol (DON) as undesirable substance in animal feed (Question $\mathrm{N}$ EFSA-Q-2003-036) Adopted on 2 June 2004 adapted 2007. EFSA Journal, 73, 1-42.

EFSA 2004d. Opinion of the Scientific Panel on Contaminants in the Food Chain on a request from the Commission related to Zearalenone as undesirable substance in animal feed (Question N_ EFSA-Q-2003-037 Adopted on 28 July 2004. EFSA Journal, 89, 1-35.

EFSA 2005. Opinion of the Scientific Panel on Contaminants in Food Chain on a request from the Commission related to fumonisins as undesirable substances in animal feed Request No. EFSA-Q-2003-040. EFSA Journal, 235.

EFSA 2011. Scientific Opinion on the risks for animal and public health related to the presence of T-2 and HT-2 toxin in food and feed. EFSA Journal, 9.

EFSA 2013. Scientific report of EFSA. Deoxynivalenol in food and feed: occurrence and exposure. EFSA Journal, 11, 3379.

El-Sayed, Y. S. \& Khalil, R. H. 2009. Toxicity, biochemical effects and residue of aflatoxin B1 in marine water-reared sea bass (Dicentrarchus labrax L.). Food and Chemical Toxicology, 47, 1606-1609.

Ellis, R. W., Clements, M., Tibbetts, A. \& Winfree, R. 2000. Reduction of the bioavailability of $20 \mu \mathrm{g} / \mathrm{kg}$ aflatoxin in trout feed containing clay. Aquaculture, 183, 179-188. 
FAO 1979. Recommended Practices for the Prevention of Mycotoxins. Pages 53-55. Food Agriculture Organization of the United nations. Rome.

FAO 2001. Safety Evaluation of Certain Mycotoxins in Food. FAO Food and Nutrition Rome, Italy.

Fegan, D. F. \& Spring, P. 2007. Recognizing the reality of the aquaculture mycotoxin problem: searching for a common and effective solution. Pages 343-354. Nutritional Biotechnology in the Feed and Food Industries, Proceedings of Alltech's 23rd Annual Symposium. The New Energy Crisis: Food, Feed or Fuel? Lexington, KY, USA, 20-23 May 2007. Alltech UK, Stamford.

Fuchs, R., Appelgren, L. E. \& Hult, K. 1986. Distribution of 14C-ochratoxin A in the rainbow trout (Salmo gairdneri). Acta Pharmacol Toxicol (Copenh), 59, 220-227.

García-Morales, M.-H., Pérez-Velázquez, M., González-Felix, M. L., Burgos-Hernández, A., Cortez-Rocha, M.-O., Bringas-Alvarado, L. \& Ezquerra-Brauer, J.-M. 2013. Effects of Fumonisin B1-Containing Feed on the Muscle Proteins and Ice-Storage Life of White Shrimp (Litopenaeus vannamei). Journal of Aquatic Food Product Technology, 24, 340-353.

Gonçalves-Nunes, E. M. C., Gomes-Pereira, M. M., Raposo-Costa, A. P., Rocha-Rosa, C. A. d., Pereyra, C. M., Calvet, R. M., Alves-Marques, A. L., Cardoso-Filho, F. \& SanchesMuratori, M. C. 2015. Screening of aflatoxin B1 and mycobiota related to raw materials and finished feed destined for fish. Latin American Journal Aquatic Research, 43, 595-600.

Gonçalves, R., Tarasco, M., Schatzmayr, D. \& Gavaia, P. 2018. Preliminary Evaluation of Moniliformin as a Potential Threat for Teleosts. Fishes, 3, 4.

Gonçalves, R. A., Hofstetter, U., Schatzmayr, D. \& Jenkins, T. 2018a. Mycotoxins in Southeast Asian aquaculture: plant-based meals and finished feeds. World Mycotoxin Journal, 11, 265-275.

Gonçalves, R. A., Naehrer, K. \& Santos, G. A. 2018. Occurrence of mycotoxins in commercial aquafeeds in Asia and Europe: a real risk to aquaculture? Reviews in Aquaculture, 10, 263-280.

Gonçalves, R. A., Navarro-Guillén, C., Gilannejad, N., Dias, J., Schatzmayr, D., Bichl, G., Czabany, T., Moyano, F. J., Rema, P., Yúfera, M., Mackenzie, S. \& Martínez-Rodríguez, G. 2018b. Impact of deoxynivalenol on rainbow trout: Growth performance, 
972

973

974

975

976

977

978

979

980

981

982

983

984

985

986

987

988

989

990

991

992

993

994

995

996

997

998

999

1000

1001

1002

1003

digestibility, key gene expression regulation and metabolism. Aquaculture, 490, 362372

Gonçalves, R. A., Schatzmayr, D., Hofstetter, U. \& Santos, G. A. 2017. Occurrence of mycotoxins in aquaculture: preliminary overview of Asian and European plant ingredients and finished feeds. World Mycotoxin Journal, 10, 183-194.

Greco, M., Pardo, A. \& Pose, G. 2015. Mycotoxigenic Fungi and Natural Co-Occurrence of Mycotoxins in Rainbow Trout (Oncorhynchus mykiss) Feeds. Toxins, 7, 4595.

Hart, S. D., Bharadwaj, A. S. \& Brown, P. B. 2010. Soybean lectins and trypsin inhibitors, but not oligosaccharides or the interactions of factors, impact weight gain of rainbow trout (Oncorhynchus mykiss). Aquaculture, 306, 310-314.

Hatai, K., S.S. Kubota, N. Kida \& Udagawa., S.-I. 1986. Fusarium oxysporum in Red Sea Bream (Pagrus spp.). Journal Wildlife Diseases, 22, 570-571.

Hessein, A., I El-Marakby, H., A Abd Rhman, G. \& Ayyat, D. M. 2014. Aflatoxin B1 toxicity and its reduction by using coumarin and vitamin E in Nile tilapia. Egyptian Journal Nutrition and Feeds, 16, 469-479.

Huang, Y., Han, D., Zhu, X., Yang, Y., Jin, J., Chen, Y. \& Xie, S. 2011. Response and recovery of gibel carp from subchronic oral administration of aflatoxin B1. Aquaculture, 319, 8997.

Hussain, D., Mateen, A. \& Gatlin lii, D. M. 2017. Alleviation of aflatoxin B1 (AFB1) toxicity by calcium bentonite clay: Effects on growth performance, condition indices and bioaccumulation of AFB1 residues in Nile tilapia (Oreochromis niloticus). Aquaculture, 475, 8-15.

Hussain, M., Gabal, M. A., Wilson, T. \& Summerfelt, R. C. 1993. Effect of aflatoxincontaminated feed on morbidity and residues in walleye fish. Veterinary and Human Toxicology, 35, 396-398.

Hussein, H. S. \& Brasel, J. M. 2001. Toxicity, metabolism and impact of mycotoxins on humans and animals. Toxicology and Applied Pharmacology, 167, 101-134.

I. Völkel, Schröer-Merker, E. \& Czerny, C. 2011. The Carry-Over of Mycotoxins in Products of Animal Origin with Special Regard to Its Implications for the European Food Safety Legislation. Food and Nutrition Sciences, 2, 852-867.

Jestoi, M. 2008. Emerging Fusarium -Mycotoxins Fusaproliferin, Beauvericin, Enniatins, And Moniliformin-A Review. Critical Reviews in Food Science and Nutrition, 48, 21-49. 
1004

1005

1006

1007

1008

1009

1010

1011

1012

1013

1014

1015

1016

1017

1018

1019

1020

1021

1022

1023

1024

1025

1026

1027

1028

1029

1030

1031

1032

1033

1034

1035

Kovalsky, P., Kos, G., Nährer, K., Schwab, C., Jenkins, T., Schatzmayr, G., Sulyok, M. \& Krska, R. 2016. Co-Occurrence of Regulated, Masked and Emerging Mycotoxins and Secondary Metabolites in Finished Feed and Maize-An Extensive Survey. Toxins, 8, 363.

Krogdahl, A., Penn. M., Thorsen, J., Refstie, S. \& Bakke, A. M. 2010. Important antinutrients in plant feedstuffs for aquaculture: an update on recent findings regarding responses in salmonids. Aquaculture Research, 41, 333-344.

Kumar, V., Roy, S., Barman, D., Kumar, A., Paul, L. \& Meetei, W. A. 2013. Importance of mycotoxins in aquaculture feeds. Aquatic Aminal Health, XVIII.

Leeman, W. R., Van Den Berg, K. J. \& Houben, G. F. 2007. Transfer of chemicals from feed to animal products: The use of transfer factors in risk assessment. Food Additive Contaminants, 24, 1-13.

Lightner, D. V., editor. 1996. A Handbook of Shrimp Pathology and Diagnostic Procedures for Diseases of Cultured Penaeid Shrimp, Baton Rouge, LA, USA.

Lopes, P. R. S., Pouey, J. L. O. F., Enke, D. B. S., Mallmann, C. A., Kich, H. A. \& Soquetta, M. B. 2009. Utilização de adsorvente em rações contendo aflatoxina para alevinos de jundiá. Revista Brasileira de Zootecnia, 38, 589-595.

Mahfouz, M. E. \& Sherif, A. H. 2015. A multiparameter investigation into adverse effects of aflatoxin on Oreochromis niloticus health status. The Journal of Basic \& Applied Zoology, 71, 48-59.

Marasas, W. F. O. 1991. Toxigenic Fusaria. Pages 119-139 in J. E. Smith, Anderson, R.A. editor. Mycotoxins and Animal Foods. CRC Press, FL.

Marijani, E., Wainaina, J. M., Charo-Karisa, H., Nzayisenga, L., Munguti, J., Joselin Benoit Gnonlonfin, G., Kigadye, E. \& Okoth, S. 2017. Mycoflora and mycotoxins in finished fish feed and feed ingredients from smallholder farms in East Africa. The Egyptian Journal of Aquatic Research, 43, 169-176.

Martins, H., Marques, M., Almeida, I., Guerra, M. \& Bernardo, F. 2008. Mycotoxins in feedstuffs in Portugal: an overview. Mycotoxin Research, 1, 19 - 23.

Michelin, E. C., Massocco, M. M., Godoy, S. H. S., Baldin, J. C., Yasui, G. S., Lima, C. G., Rottinghaus, G. E., Sousa, R. L. M. \& Fernandes, A. M. 2017. Carryover of aflatoxins from feed to lambari fish (Astyanax altiparanae) tissues. Food Additives \& Contaminants: Part A, 34, 265-272. 
1036

1037

1038

1039

1040

1041

1042

1043

1044

1045

1046

1047

1048

1049

1050

1051

1052

1053

1054

1055

1056

1057

1058

1059

1060

1061

1062

1063

1064

1065

1066

1067

Minervini, F. \& Aquila, M. E. D. 2008. Zearalenone and reproductive function in farm animals. International Journal of Molecular Sciences, 9, 2570-2584.

Miraglia, M., Marvin, H. J. P., Kleter, G. A., Battilani, P., Brera, C., Coni, E., Cubadda, F., Croci, L., De Santis, B., Dekkers, S., Filippi, L., Hutjes, R. W. A., Noordam, M. Y., Pisante, M., Piva, G., Prandini, A., Toti, L., van den Born, G. J. \& Vespermann, A. 2009. Climate change and food safety: An emerging issue with special focus on Europe. Food and Chemical Toxicology, 47, 1009-1021.

Nácher-Mestre, J., Serrano, R., Beltrán, E., Pérez-Sánchez, J., Silva, J., Karalazos, V., Hernández, F. \& Berntssen, M. H. G. 2015. Occurrence and potential transfer of mycotoxins in gilthead sea bream and Atlantic salmon by use of novel alternative feed ingredients. Chemosphere, 128, 314-320.

Ngethe, S., Horsberg, T. E. \& Ingebrigtsen, K. 1992. The disposition of ${ }^{3} \mathrm{H}$-aflatoxin B1 in the rainbow trout (Oncorhynchus mykiss) after oral and intravenous administration. Aquaculture, 108, 323-332.

Ngethe, S., Horsberg, T. E., Mitema, E. \& Ingebrigtsen, K. 1993. Species differences in hepatic concentration of orally administered ${ }^{3} \mathrm{H}$-AFB1 between rainbow trout (Oncorhynchus mykiss) and tilapia (Oreochromis niloticus). Aquaculture, 114, 355-358.

Nguyen, A., Manning, B., Lovell, R. \& Rottinghaus, G. 2003. Responses of Nile tilapia (Oreochromis niloticus) fed diets containing different concentrations of moniliformin or fumonisin B1. Aquaculture, 217, 515 - 528.

Ostland V.E., H.W. Ferguson, R.D. Armstrong, A. Asselin \& Hall., R. 1987. Granulomatous peritonitis in fish associated with Fusarium solani. Veterinary Record, 121, 595-596.

Paterson, R. R. M. \& Lima, N. 2010. How will climate change affect mycotoxins in food? Food Research International, 43, 1902-1914.

Paterson, R. R. M. \& Lima, N. 2011. Further mycotoxin effects from climate change. Food Research International, 44, 2555-2566.

Pietsch, C., Kersten, S., Burkhardt-Holm, P., Valenta, H. \& Dänicke, S. 2013. Occurrence of Deoxynivalenol and Zearalenone in Commercial Fish Feed: An Initial Study. Toxins, 5, 184.

Pietsch, C., Kersten, S., Valenta, H., Dänicke, S., Schulz, C., Burkhardt-Holm, P. \& Junge, R. 2015. Effects of Dietary Exposure to Zearalenone (ZEN) on Carp (Cyprinus carpio L.). Toxins, 7, 3465. 
Pietsch, C., Michel, C., Kersten, S., Valenta, H., Dänicke, S., Schulz, C., Kloas, W. \& BurkhardtHolm, P. 2014. In vivo effects of deoxynivalenol (DON) on innate immune responses of carp (Cyprinus carpio L.). Food and Chemical Toxicology, 68, 44-52.

Pitt, J. I. 2014. Mycotoxins: Aflatoxins. Pages 289-294 in Y. Motarjemi editor. Encyclopedia of Food Safety. Academic Press, Waltham.

Rajeev Raghavan, P., Zhu, X., Lei, W., Han, D., Yang, Y. \& Xie, S. 2011. Low levels of Aflatoxin B1 could cause mortalities in juvenile hybrid sturgeon, Acipenser ruthenus ơ $x$. baeri 9 . Aquaculture Nutrition, 17, e39-e47.

SALEM, M. F. I., EL-RAOU, E. M. A., EWEEDAH, N. M. \& MOHAMED, B. S. 2009. Influence of some medicinal plants as antimycotoxins in Nile tilapia (Oreochromis niloticus) diets. International Journal for Aquaculture, 227-242.

Selim, K., El-hofy, H. \& Khalil, R. 2014. The efficacy of three mycotoxin adsorbents to alleviate aflatoxin B1-induced toxicity in Oreochromis niloticus. Aquaculture International, 22, 523-540.

Shane, S. H. \& Eaton, D. L. 1994. Economic issues associated with aflatoxins. Pages 513-527 in J. D. Groopman editor. The Toxicology of Aflatoxins: Human Health, Veterinary, and Agricultural Significance. Academic Press, San Diego.

Souheil, H., A. Vey, P. Thuet \& Trilles., J.-P. 1999. Pathogenic and toxic effects of Fusarium oxysporum (Schecht.) on survival and osmoregulatory capacity of Penaeus japonicus (Bate). Aquaculture, 178, 209-224.

Supamattaya, K., Bundit, O., Boonyarapatlin, M., Schatzmayr, G. \& Chittiwan, V. 2005a. Effects of mycotoxin T-2 and zearalenone on histopathological changes in black tiger shrimp (Penaeus monodon Fabricius). Journal of Science Technology, 27, 91-99.

Supamattaya, K., Noppadon, S., Mali, B., Dian, S. \& Vuttikorn, C. 2005b. Effects of ochratoxin A and deoxynivalenol on growth performance and immuno-physiological parameters in black tiger shrimp (Penaeus monodon). Songklanakarin Journal of Science and Technology, 27, 91-99

Suzy, S. K., Thomas, E. E., Raphael, K. J., Christelle, T. T., Peguy, T. A. \& Joseph, T. 2017. Effect of Aflatoxin B1 on growth performance of Clarias Gariepinus Fry (Burchell, 1822) in West Cameroon. International Journal of Agronomy and Agriculture Research, 10, 3341. 
Tacon, A. G. J., Hasan, M. R. \& Metian, M. 2011. Demand and supply of feed ingredients for farmed fish and crustaceans: trends and prospects. FAO Fisheries and Aquaculture, Technical Paper No. 564, 87.

Tolosa, J., Font, G., Mañes, J. \& Ferrer, E. 2013. Natural occurrence of Fusarium mycotoxins in aquaculture fish food. Revista de Toxicología [online], 30, 193-197.

Trigo-Stockli, D. M., Obaldo, L. G., Dominy, W. G. \& Behnke, K. C. 2000. Utilization of Deoxynivalenol-Contaminated Hard Red Winter Wheat for Shrimp Feeds. Journal of the World Aquaculture Society, 31, 247-254.

Tuan, N. A., Manning, B. B., Lovell, R. T. \& Rottinghaus, G. E. 2003. Responses of Nile tilapia (Oreochromis niloticus) fed diets containing different concentrations of moniliformin or fumonisin B1. Aquaculture, 217, 515-528.

Usanno, O., Chaisilapasung, S., Sukrakanchana, N. \& Supamattaya, K. 2005. Effects of aflatoxin B1 on sex reversed red tilapia (Oreochromis niloticus Linn. $\times$ O. mossambicus Peters). Songklanakarin Journal of Science and Technology, 27, 187-197.

Vasanthi, S. \& Bhat, R. V. 1998. Mycotoxins in foods-occurrence, health \& economic significance \& food control measures. Indian Journal of Medical Research, 108, 212224.

Woźny, M., Dobosz, S., Obremski, K., Hliwa, P., Gomułka, P., Łakomiak, A., Różyński, R., Zalewski, T. \& Brzuzan, P. 2015. Feed-borne exposure to zearalenone leads to advanced ovarian development and limited histopathological changes in the liver of premarket size rainbow trout. Aquaculture, 448, 71-81.

Woźny, M., Obremski, K., Jakimiuk, E., Gusiatin, M. \& Brzuzan, P. 2013. Zearalenone contamination in rainbow trout farms in north-eastern Poland. Aquaculture, 416417, 209-211.

Woźny, M., Obremski, K., Zalewski, T., Mommens, M., Łakomiak, A. \& Brzuzan, P. 2017. Transfer of zearalenone to the reproductive system of female rainbow trout spawners: A potential risk for aquaculture and fish consumers? Food and Chemical Toxicology, 107, 386-394.

Yildirim, M., Manning, R., Lovell, J. \& Grizzle, R. 2000. Toxicity of moniliformin and fumonisin B1 fed singly and in combination in diets for channel catfish. Journal World Aquaculture Society, 31, 599 - 608. 
1130

1131

1132

1133

1134

1135

1136

1137

Zain, M. E. 2011. Impact of mycotoxins on humans and animals. Journal of Saudi Chemical Society, 15, 129-144.

Zinedine, A., Soriano, J. M., Moltó, J. C. \& Mañes, J. 2007. Review on the toxicity, occurrence, metabolism, detoxification, regulations and intake of zearalenone: an oestrogenic mycotoxin. Food and Chemical Toxicology, 45, 1-18. 
Table 1: Documented mycotoxin occurrence in aquaculture feeds.

\begin{tabular}{|c|c|c|c|c|c|c|c|c|c|}
\hline Reference & Sampling year(s) & Sampling Country & $\begin{array}{l}\text { Sampling } \\
\text { local }\end{array}$ & $\begin{array}{l}\text { Number } \\
\text { of } \\
\text { samples }\end{array}$ & $\begin{array}{l}\text { Species to } \\
\text { which the } \\
\text { feed is } \\
\text { intended }\end{array}$ & $\begin{array}{l}\text { Target mycotoxin } \\
\text { analysed in feed }\end{array}$ & $\begin{array}{l}\text { Mycotoxin detection level } \\
\qquad\left(\mu \mathrm{g} \mathrm{kg}^{-1}\right)\end{array}$ & $\begin{array}{l}\text { Method } \\
\text { of } \\
\text { analysis }\end{array}$ & Observations \\
\hline $\begin{array}{l}\text { Bautista et } \\
\text { al. } 1994\end{array}$ & $\begin{array}{l}\text { August } 1990- \\
\text { February } 1991 \\
\text { (rainy season) }\end{array}$ & Philippines & $\begin{array}{l}\text { Feed plant } \\
\text { Farm level }\end{array}$ & $n=62$ & $\begin{array}{l}\text { Black tiger } \\
\text { shrimp }\end{array}$ & $\mathrm{AFB}_{1}$ & $\begin{array}{l}\mathrm{n}=2->\text { none detected } \\
\mathrm{n}=36->10 \text { to } 20 \mu \mathrm{kg}^{-1} \mathrm{AFB}_{1} \\
\mathrm{n}=21->30 \text { to } 40 \mu \mathrm{kg}^{-1} \mathrm{AFB}_{1} \\
\mathrm{n}=2->60 \text { to } 120 \mu \mathrm{gg}^{-1} \mathrm{AFB}_{1}\end{array}$ & HPTLC & -.---- \\
\hline $\begin{array}{l}\text { Bintvihok et } \\
\text { al. } 2003\end{array}$ & $\begin{array}{l}{ }^{\mathrm{S} S u m m e r} \text { (March - } \\
\text { June 1997) } \\
{ }^{\mathrm{R}} \text { Rainy (July - } \\
\text { October 1997) } \\
{ }^{\mathrm{W}} \text { Winter } \\
\text { (November - } \\
\text { February 1998) }\end{array}$ & $\begin{array}{l}\text { Thailand } \\
\text { (Eastern and Southern } \\
\text { regions) }\end{array}$ & Farm level & $\begin{array}{l}\mathrm{N}_{\mathrm{t}}=150 \\
\text { (50 samples } \\
\text { from } 10 \\
\text { different } \\
\text { regions } \\
\text { during } 3 \\
\text { seasons) }\end{array}$ & $\begin{array}{l}\text { Black tiger } \\
\text { shrimp }\end{array}$ & $\begin{array}{l}\mathrm{AFB}_{1} \\
\mathrm{AFB} \\
\mathrm{AFG} \\
\mathrm{AFG}\end{array}$ & $\begin{array}{l}\text { Eastern region } \\
{ }^{\mathrm{s}} 0.003-0.012 \\
{ }^{\mathrm{R}} 0.003-0.651 \\
{ }^{\mathrm{W}} 0.003-0.314 \\
\text { Southern region } \\
{ }^{\mathrm{s}} 0.004 \\
{ }^{\mathrm{R}} 0.003-0.058 \\
{ }^{\mathrm{W}} 0.003-0.022\end{array}$ & HPLC & $\begin{array}{l}\text { - Feeds composed mainly of fishmeal, } \\
\text { soybean and corn (no information on } \\
\text { ingredient inclusion levels or finished feed } \\
\text { storage period) }\end{array}$ \\
\hline $\begin{array}{l}\text { Altuğ et al. } \\
2001\end{array}$ & 1998, 1999, 2000 & Turkey & $\begin{array}{l}\text { Farm level } \\
\text { Feed plant } \\
\text { Imported } \\
\text { feeds }\end{array}$ & $n=170$ & $\begin{array}{l}\text { Rainbow trout } \\
\text { Seabream } \\
\text { Pike-perch }\end{array}$ & $\mathrm{AFB}_{1}$ & $\begin{array}{l}\mathrm{n}=20>20 \mu \mathrm{gg}^{-1} \\
\mathrm{n}=85=21.2 \text { to } 42.4 \mu \mathrm{g} \mathrm{kg}^{-1} \\
\mathrm{n}=22=5.0 \text { to } 20.0 \mu \mathrm{g} \mathrm{kg}^{-1} \\
\mathrm{n}=43<\mathrm{LOD}\end{array}$ & $\begin{array}{l}\text { TLC } \\
\text { ELISA }\end{array}$ & $\begin{array}{l}\text { - Level of aflatoxins were higher in } \\
\text { samples that were taken from farm level } \\
\text { compared to feed plant or imported feed } \\
\text { samples }\end{array}$ \\
\hline $\begin{array}{l}\text { Alinezhad } \\
\text { et al. } 2011\end{array}$ & $\begin{array}{l}\text { March - July } \\
2009 \\
\text { (1 sample per month) }\end{array}$ & Iran & Feed plant & $n=6$ & Rainbow trout & $\mathrm{AFB}_{1}$ & 0.12 to $20.09 \mu \mathrm{g} \mathrm{kg}^{-1} \mathrm{AFB}_{1}$ & HPLC & $\begin{array}{l}\text { - High concentrations of } A_{F B} \text { in fishmeal } \\
\left(\bar{x}=67.35{\mu \mathrm{ggg}^{-1}}^{-1}\right) \text { and soybean meal }(\bar{x}= \\
\left.30.88 \mu \mathrm{kg}^{-1}\right)\end{array}$ \\
\hline $\begin{array}{l}\text { Fegan \& } \\
\text { Spring, } \\
2007\end{array}$ & $\mathrm{n} / \mathrm{a}$ & $\begin{array}{l}{ }^{\mathrm{IN}} \text { India } \\
{ }_{\mathrm{TH}} \text { Thailand }\end{array}$ & $\mathrm{n} / \mathrm{a}$ & $\begin{array}{l}{ }^{I N, S} \mathrm{n}=10 \\
\mathrm{TH}, \mathrm{S} n=7 \\
\mathrm{TH} \mathrm{F} \mathrm{n}=9\end{array}$ & $\begin{array}{l}\text { Shrimp } \\
\text { Fish }^{\mathrm{F}}\end{array}$ & $\begin{array}{l}{ }^{I N, S}(A F, T-2, Z E N) \\
T H, S(T-2, Z E N, O T A) \\
T H, F(T-2, Z E N, O T A)\end{array}$ & 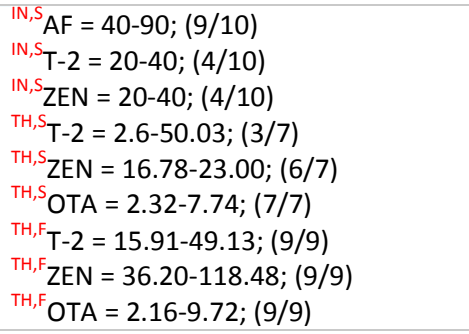 & $\mathrm{n} / \mathrm{a}$ & $\begin{array}{l}\text { - Marine ingredients (fishmeal from } \\
\text { China, Myanmar, Thailand; fish and } \\
\text { shrimp meal from Thailand) contaminated } \\
\text { with T-2, ZEN and OTA }\end{array}$ \\
\hline $\begin{array}{l}\text { Goncalves- } \\
\text { nunes et al. } \\
2015\end{array}$ & $\begin{array}{l}\text { January - March } \\
2009\end{array}$ & $\begin{array}{l}\text { Brazil } \\
\text { (Piauí State) }\end{array}$ & Feed plant & $\mathrm{n}=18$ & Fish & $\mathrm{AFB}_{1}$ & $1.6-9.8$ & ELISA & $\begin{array}{l}\text { - Finished feed samples were composed } \\
\text { of soybean bran }(15 \%) \text {, corn bran }(27 \%) \text {, } \\
\text { other cereals }(57.5 \%) \text {. }\end{array}$ \\
\hline $\begin{array}{l}\text { Barbosa et } \\
\text { al. } 2013\end{array}$ & $\begin{array}{l}\text { September } 2009 \\
\text { and August } 2010\end{array}$ & $\begin{array}{l}\text { Brasil } \\
\text { (Rio de Janeiro State) }\end{array}$ & & $n=60$ & $\mathrm{n} / \mathrm{a}$ & $\begin{array}{l}\mathrm{FB}_{1} \\
\mathrm{AFB}_{1} \\
\mathrm{OTA}\end{array}$ & $\begin{array}{l}\mathrm{FB}_{1}=(90 \%) 0.3-4.94 ; \overline{\mathrm{x}}=2.6 \\
\mathrm{AFB}_{1}=\text { present in } 55 \% \text { of the samples } \\
\mathrm{OTA}=\text { present in } 3.3 \% \text { of the samples }\end{array}$ & $\begin{array}{l}\mathrm{FB}_{1} \text { - ELISA } \\
\mathrm{AFB}_{1} \text { and } \\
\mathrm{OTA}-\mathrm{TLC}\end{array}$ & $\begin{array}{l}\text { LOD: } \\
\left.=0.2 \mu \mathrm{g} \mathrm{g}^{-1} \text { for ELISA (FB }{ }_{1}\right) \\
=0.003 \text { and } 0.005 \mu \mathrm{g} \mathrm{g}^{-1} \text { for TLC ( } \mathrm{AFB}_{1} \text { and } \\
\text { OTA) } \\
=50 \% \text { of samples had co-occurrence of }\end{array}$ \\
\hline
\end{tabular}




\begin{tabular}{|c|c|c|c|c|c|c|c|c|c|}
\hline & 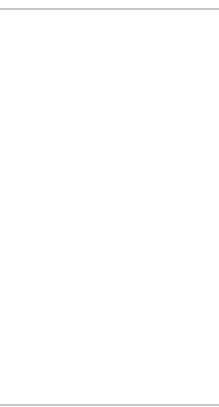 & (CR, PT) & & $\begin{array}{l}n=6-10 \\
\text { Europe }\end{array}$ & & OTA & $\begin{array}{l}(21 / 31) \\
{ }^{A} \text { FUM: } \bar{x}=172.63 ; \operatorname{Max}=573.32 ; \\
(18 / 31) \\
{ }^{A} \text { OTA }: \bar{x}=2.11 ; \operatorname{Max}=5.05 ;(17 / 31) \\
\text { AF: } \bar{x}=0.43 ; \operatorname{Max}=0.43 ;(1 / 6) \\
{ }^{E} \text { ZEN: }: \bar{x}=118.01 ; \operatorname{Max}=305.89 ; \\
(4 / 6) \\
{ }^{E D O N}: \bar{x}=165.61 ; \operatorname{Max}=281.72(4 / 6) \\
{ }^{E} \text { FUM: }: \bar{x}=3419.92 ; \operatorname{Max}=7533.61 ; \\
(3 / 10) \\
{ }^{E} \text { OTA }: \bar{x}=1.53 ; \operatorname{Max}=3.1 ;(4 / 6)\end{array}$ & & \\
\hline $\begin{array}{l}\text { Gonçalves } \\
\text { et al. } 2017\end{array}$ & $\begin{array}{l}\text { January- } \\
\text { December } 2015\end{array}$ & $\begin{array}{l}{ }^{\mathrm{A}} \text { Asia } \\
\text { (VN, ID, MM) } \\
\mathrm{E}^{\mathrm{E}} \text { Europe } \\
\text { (DK, AT, NL, DE) }\end{array}$ & $\begin{array}{l}\text { Farm level } \\
\text { Feed plant }\end{array}$ & $\begin{array}{l}N_{t}=25 \\
A_{n=21} \\
(20 / 21) \\
E_{n=4} \\
(4 / 4)\end{array}$ & $\begin{array}{l}\text { Shrimp } \\
\text { Fish }\end{array}$ & $\begin{array}{l}\text { AF } \\
\text { ZEN } \\
\text { DON } \\
\text { FUM } \\
\text { OTA }\end{array}$ & 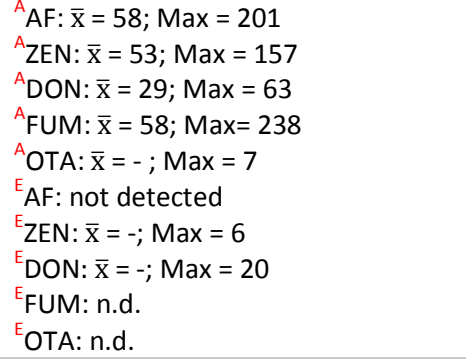 & HPLC & ---- \\
\hline $\begin{array}{l}\text { Marijani et } \\
\text { al. } 2017\end{array}$ & $\mathrm{n} / \mathrm{a}$ & $\begin{array}{l}\text { Kenya } \\
\text { Kisumu } \rightarrow n=16 \\
\text { Tanzania } \\
\text { Ukerewe } \rightarrow n=13 \\
\text { Rwanda } \\
\text { Kigembe } \rightarrow n=10 \\
\text { Uganda } \\
\text { Jinja } \rightarrow \mathrm{n}=13\end{array}$ & $\begin{array}{l}{ }^{\mathrm{FM}} \text { Farm } \\
\text { LFP Local } \\
\text { feed plant } \\
{ }_{\mathrm{IF}} \text { Imported } \\
\text { feed (from } \\
\text { Israel and } \\
\text { India) } \\
{ }^{\mathrm{F} \mid} \text { Feed } \\
\text { Ingredient } \\
\mathrm{S}\end{array}$ & $\begin{array}{l}N_{t}=52 \\
F M n=14 \\
F_{n} n P_{n}=14 \\
{ }^{I F} n=12 \\
F F_{n}=12\end{array}$ & $\begin{array}{l}\text { Nile tilapia } \\
\text { African } \\
\text { catfish }\end{array}$ & $\begin{array}{l}\text { 3-ADON } \\
\text { 15-ADON } \\
\text { DON } \\
\text { AF } \\
\text { DAS } \\
\text { AOH } \\
\text { FB } 1 \\
\text { FB }_{3} \\
\text { OTA } \\
\text { ROQ-C }\end{array}$ & $\begin{array}{l}{ }^{\mathrm{FM}} \mathrm{AF}=2.4-126 ; \overline{\mathrm{x}}=71.0 \pm 31.5 \\
{ }_{\mathrm{FM}} \mathrm{FUM}=33.2-2834.6 ; \overline{\mathrm{x}}=1136.5 \pm \\
717.9 \\
{ }_{\mathrm{FM}} \mathrm{DON}=69.1-755.4 ; \overline{\mathrm{x}}=245.8 \pm \\
190.1 \\
{ }^{\mathrm{LFM}} \mathrm{AF}=<2-28 ; \overline{\mathrm{x}}=11.6 \pm 0.7 \\
{ }^{\mathrm{LFM}} \mathrm{FUM}, \mathrm{DON}=<\mathrm{LOD} \\
{ }^{\mathrm{IF}} \mathrm{AF}=<2-2.6 ; \overline{\mathrm{x}}=1.4 \pm 0.9 \\
{ }^{\mathrm{I}} \mathrm{F} \mathrm{FUM}, \mathrm{DON}=<\mathrm{LOD}\end{array}$ & $\begin{array}{l}\text { LC- } \\
\text { MS/MS }\end{array}$ & $\begin{array}{l}\text { - Farmers who formulate their own feed } \\
\text { used: sunflower seed cake, rice bran, } \\
\text { cotton seed cake, maize bran and } \\
\text { soybean. } \\
\text { - Feeds co-contaminated with } 12^{\mathrm{FM}}, 4^{\mathrm{LFM}} \\
\text { and } 5^{\mathrm{F}} \text { mycotoxins. } \\
\text { - NEO, FUX and STERIG were not detected } \\
\text { in any of the samples } \\
\text { - AF co-occurred with FUM in } 13 \text { of } 24 \\
\text { feed samples } \\
\text { - DON co-occurred with FUM in } 2 \text { of } 24 \\
\text { feed samples }\end{array}$ \\
\hline $\begin{array}{l}\text { Gonçalves } \\
\text { et al. } 2018\end{array}$ & $\begin{array}{l}\text { January - } \\
\text { December } 2016\end{array}$ & $\begin{array}{l}\text { Asia } \\
\text { (SAS: IN, ID, MN, TW, TH) }\end{array}$ & $\begin{array}{l}\text { Farm level } \\
\text { Feed plant }\end{array}$ & $\begin{array}{l}\mathrm{N}_{\mathrm{t}}=16 \\
\mathrm{~S}_{\mathrm{n}}=4 \\
\mathrm{~F}_{\mathrm{n}}=12\end{array}$ & $\begin{array}{l}\text { Shrimp } \\
\text { Fish }^{\mathrm{F}}\end{array}$ & $\begin{array}{l}\text { AF } \\
\text { ZEN } \\
\text { DON } \\
\text { FUM } \\
\text { OTA } \\
\text { NIV } \\
\text { 3-ACDON } \\
\text { 15-ACDON } \\
\text { FUX }\end{array}$ & 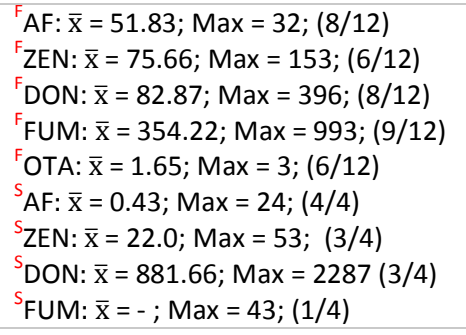 & $\begin{array}{l}\text { LC- } \\
\text { MS/MS }\end{array}$ & --.-- \\
\hline
\end{tabular}




T-2
HT-2
DASA: $\overline{\mathrm{x}}=2.66 ; \mathrm{Max}=4 ;(3 / 4)$
NEO

Reference entries are in chronological ordered by sampling date collection or publishing date. Superscript letters give extra information; they are only valid for the same row.

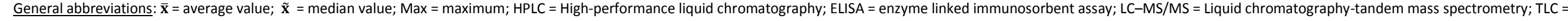
Thin layer chromatography; HPTLC = high performance thin layer chromatography ; LOD = limit of detection; $n$.d. = not detected

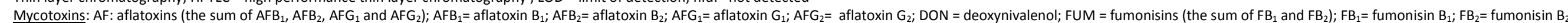

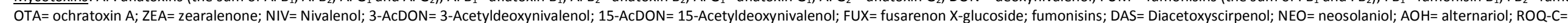
roquefortine $C ;$ STERIG= sterigmatocystin.

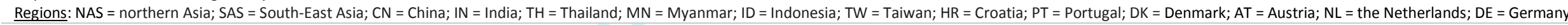

$$
1138
$$

1139

Table 2: Documented aflatoxin carry-over on aquaculture species

\begin{tabular}{|c|c|c|c|c|c|c|}
\hline Reference & Species & Tested dosage & $\begin{array}{l}\text { Mycotoxin detection } \\
\text { level }\left(\mu \mathrm{g} \mathrm{kg}^{-1}\right)\end{array}$ & factor & Method of analysis & Observations \\
\hline \multicolumn{7}{|l|}{ Fish studies } \\
\hline Suzy et al. 2017 & $\begin{array}{l}\text { African sharptooth } \\
\text { catfish } \\
\text { (Clarias Gariepinus) }\end{array}$ & $10^{1}, 17^{2}$ and $20^{3} \mu \mathrm{g} \mathrm{AFB}_{1} \mathrm{~kg}^{-1}$ & $\begin{array}{l}\mathrm{M}^{1}=0.05 \pm 0.12 \mu \mathrm{g} \mathrm{AFB}_{1} \mathrm{~kg}^{-1} \\
\mathrm{M}^{2}=0.08 \pm 0.10 \mu \mathrm{AFB}_{1} \mathrm{~kg}^{-1} \\
\mathrm{M}^{3}=0.08 \pm 0.12 \mu \mathrm{AFB}_{1} \mathrm{~kg}^{-1}\end{array}$ & $\begin{array}{l}M^{1}=0.005 \\
M^{2}=0.005 \\
M^{3}=0.004\end{array}$ & ELISA & $\begin{array}{l}\text { - Initial weight: } 4 \pm 2 \mathrm{~g} ; 3 \text { month study } \\
\text { - Chicken droppings were used as ingredient contaminated } \\
\text { with } 5,7.2 \text { and } 8.2 \mu \mathrm{gFB}_{1} \mathrm{~kg}^{-1} \\
\text { - Catfish fed } 10 \mu \mathrm{gFB}_{1} \mathrm{~kg}^{-1} \text { used as control } \\
\text { - No differences in haematological parameters }\end{array}$ \\
\hline $\begin{array}{l}\text { El-Sayed and } \\
\text { Khalil, } 2009\end{array}$ & $\begin{array}{l}\text { European seabass } \\
\text { (Dicentrarchuslabrax) }\end{array}$ & $\begin{array}{l}{ }^{\# 1} \text { Oral } 96 \mathrm{~h} \mathrm{LC} 50 \\
>0.05,0.10,0.15,0.20,0.25 \\
0.30,0.35 \text { and } 0.40 \mathrm{mg} \mathrm{kg}^{-1} \\
{ }^{2} 42 \text { day exposure to } 10 \% \text { of } \\
\text { oral } 96 \mathrm{~h} \mathrm{LC}_{50}=180 \mu \mathrm{gg}^{-1}\end{array}$ & $\begin{array}{l}{ }^{\# 2} \mathrm{M}=4.25 \pm 0.85 \mu \mathrm{g} \mathrm{AFB}_{1} \\
\mathrm{~kg}^{-1}\end{array}$ & ${ }^{\# 2} \mathrm{M}=0.236$ & ELISA & $\begin{array}{l}\text { - Initial weight: } 40 \pm 2 \mathrm{~g} \\
{ }^{\# 1} 96 \mathrm{~h} \mathrm{LC}_{50}=0.18 \mathrm{mg} / \mathrm{kg} \text { bwt } \\
\text { - }{ }^{\# 2} 0.018 \mathrm{mg} / \mathrm{kg} \text { bwt AFB } \\
\text {. }{ }^{\# 1,2} \text { Clinical signs: sluggish movement, loss of equilibrium, } \\
\text { rapid opercular movement, and hemorrhages of the dorsal } \\
\text { skin surface. }{ }^{\# 2} \text { Yellowish discoloration, pale discoloration of } \\
\text { the gills, liver and kidney. Severe distension of the gall } \\
\text { bladder. }\end{array}$ \\
\hline $\begin{array}{l}\text { Huang et al. } \\
2011\end{array}$ & $\begin{array}{l}\text { Gibel carp } \\
\text { (Carassius gibelio) }\end{array}$ & $\begin{array}{l}\text { 3.2, } 11.3,20.2^{1}, \\
55.2^{2}, 95.8^{3}, 176.0^{4} \text { and } 991.5^{5} \\
\mu \mathrm{g} \mathrm{AFB} \mathrm{kg}^{-1}\end{array}$ & $\begin{array}{l}\mathrm{L}^{1-5}>5 \mu \mathrm{g} \mathrm{AFB}_{1} \mathrm{~kg}^{-1} \\
\mathrm{M}^{5}=2.35 \mu \mathrm{AFB}_{1} \mathrm{~kg}^{-1}\end{array}$ & $\begin{array}{l}\mathrm{HP}^{1-5^{*}}>0.090 \\
\mathrm{M}^{5}=0.0024\end{array}$ & ELISA & $\begin{array}{l}\text { - Initial weight: } 10.33 \pm 0.19 \mathrm{~g} \\
\text { - } 12 \text { week study } \\
\text { - Fish showed strong clearance ability of } \mathrm{AFB}_{1}\end{array}$ \\
\hline $\begin{array}{l}\text { Raghavan et al. } \\
2011\end{array}$ & $\begin{array}{l}\text { Hybrid sturgeon } \\
\text { (Acipenser ruthenusx A. } \\
\text { baeri) }\end{array}$ & $\begin{array}{l}0,1,5,10,20,40^{1} \text { and } 80^{2} \mu g \\
\mathrm{AFB}_{1} \mathrm{~kg}^{-1}\end{array}$ & $\begin{array}{l}M \approx 28^{1} \text { and } 34^{2} \\
L=142.80^{1}\end{array}$ & $\begin{array}{l}M^{1}=0.7 \\
M^{2}=0.425\end{array}$ & ELISA & $\begin{array}{l}\text { - Initial weight: } 10.53 \pm 0.17 \mathrm{~g} \\
\text { - } 35 \text { day study }\end{array}$ \\
\hline
\end{tabular}




\begin{tabular}{|c|c|c|c|c|c|c|}
\hline & & & and $115.60^{2} \mu \mathrm{g} \mathrm{kg}^{-1}$ & $\begin{array}{l}L^{1}=3.57 \\
L^{2}=1.15\end{array}$ & & $\begin{array}{l}\text { - Liver hypertrophy and hyperchromasia of nuclei and } \\
\text { cytoplasmic vacuoles, presence of inflammatory cells, focal } \\
\text { hepatocyte necrosis and extensive biliary hyperplasia. }\end{array}$ \\
\hline $\begin{array}{l}\text { Lopes et al. } \\
2005\end{array}$ & $\begin{array}{l}\text { Jundiá } \\
\text { (Rhamdia quelen) }\end{array}$ & $\begin{array}{l}\# 141,90^{1} \text { and } 204^{2} \mu g \mathrm{AFB}_{1} \\
\mathrm{~kg}^{-1} \\
{ }_{\# 2} 350^{1} ; 757^{2} ; 1,177^{3} \mu \mathrm{g} \mathrm{AFB}{ }_{1} \\
\mathrm{~kg}^{-1}\end{array}$ & $\begin{array}{l}{ }^{\# 1} \mathrm{M}=1^{1} \text { and } 6.1^{2} \mu \mathrm{AFB}_{1} \\
\mathrm{~kg}^{-1} \\
{ }^{* 2} \mathrm{M}+\mathrm{L}=350^{1} ; 757^{2} \mu \mathrm{kg}^{-1} \\
\text { and } 1,177^{3} \mu \mathrm{AFB}_{1} \mathrm{~kg}^{-1}\end{array}$ & $\begin{array}{l}{ }^{\# 1} M^{1}=0.024 \\
{ }^{\# 1} M^{2}=0.030 \\
{ }^{\# 2} M+L^{1}=1 \\
{ }^{\# 2} M+L^{2}=1 \\
{ }^{\# 2} M+L^{3}=1\end{array}$ & HPLC & $\begin{array}{l}\text { - Initial weight: } 3.21^{111} \mathrm{~g} \text { and } 4.73^{122} \mathrm{~g} \\
=45^{111} \text { and } 35^{42} \text { day studies }\end{array}$ \\
\hline $\begin{array}{l}\text { Michelin et al. } \\
2016\end{array}$ & $\begin{array}{l}\text { Lambari fish } \\
\text { (Astyanax altiparanae) }\end{array}$ & $\begin{array}{l}0,10^{1}, 20^{2} \text { and } 50^{3} \mu \mathrm{AFB}{ }_{1} \\
\mathrm{~kg}^{-1}\end{array}$ & $\begin{array}{l}\mathrm{L}=265^{2, \mathrm{t}} \text { and } 243^{3, \mathrm{t}} \mu \mathrm{g} \mathrm{kg} \mathrm{g}^{-1} \\
\mathrm{M}=19^{1, \mathrm{t}}, 20^{2, \mathrm{t}} \text { and } 50^{3, \mathrm{t}} \mu \mathrm{g} \\
\mathrm{kg}^{-1}\end{array}$ & $\begin{array}{l}\mathrm{L}^{2, \mathrm{t}}=13.25 \\
\mathrm{~L}^{3, \mathrm{t}}=4.86 \\
\mathrm{M}^{1, \mathrm{t}}=1.9 \\
\mathrm{M}^{2, \mathrm{t}}=1 \\
\mathrm{M}^{3, \mathrm{t}}=1\end{array}$ & HPLC & $\begin{array}{l}\text { - Initial weight: } 3.15 \mathrm{~g} \\
\text { : } 120 \text { day study (sampling at day } 30,60,90 \text { and } 120^{\dagger} \text { ) } \\
\text { - For the first } 60 \text { days of exposure, AFs were metabolised } \\
\text { by liver and excreted. After } 90 \text { days, a lower efficiency in } \\
\text { the elimination of AFs }\end{array}$ \\
\hline $\begin{array}{l}\text { Abdel Rahman } \\
\text { et al. } 2017\end{array}$ & $\begin{array}{l}\text { Nile tilapia } \\
\text { (Oreochromisniloticus) }\end{array}$ & $\begin{array}{l}\left(0 \text { and } 200^{1} \mu \mathrm{AFB}_{1} \mathrm{~kg}^{-1}\right) \mathrm{x} \\
(\mathrm{FEO}+\mathrm{SC})\end{array}$ & $\begin{array}{l}\mathrm{L}^{1}=5 \pm 0.5 \mu \mathrm{g} \mathrm{AFB} \mathrm{kg}^{-1} \\
\mathrm{M}^{1}=3.7 \pm 0.1 \mu \mathrm{\mu gFB} \mathrm{kg}^{-1}\end{array}$ & $\begin{array}{l}\mathrm{L}^{1}=0.025 \\
\mathrm{M}^{1}=0.019\end{array}$ & HPLC & $\begin{array}{l}\text { - Initial weight: } 26.6 \pm 0.12 \mathrm{~g} ; 30 \text { day study } \\
\text { - Tested fennel essential oil (FEO) and saccharomyces } \\
\text { cerevisiae (SC) as mycotoxin management strategy- } \\
\text { - AF effects are reported only for } 0 \text { and } 200^{1} \mathrm{\mu g} \mathrm{kg}^{-1}\end{array}$ \\
\hline $\begin{array}{l}\text { Ayyat et al. } \\
2013\end{array}$ & $\begin{array}{l}\text { Nile tilapia } \\
\text { (Oreochromisniloticus) }\end{array}$ & $\begin{array}{l}\left(0,250^{1} \mu \mathrm{gAFB}_{1} \mathrm{~kg} \mathrm{feed}^{-1}\right) \mathrm{x} \\
\mathrm{OZ}, \mathrm{B} \text { or C }\end{array}$ & $\mathrm{M}^{1}=78.33 \mu \mathrm{g} \mathrm{kg}^{-1}$ & $M^{1}=0.313$ & HPLC & $\begin{array}{l}\text { - Initial weight: } 7.3 \mathrm{~g} ; 3 \text { week study } \\
\text { - Tested ozone }(0.5 \mathrm{mg} / \mathrm{L} / \mathrm{minute} ; \mathrm{OZ}) \text {, bentonite }(20 \mathrm{~g} / \mathrm{kg} \\
\text { diet; B) and coumarin }(5 \mathrm{~g} / \mathrm{kg} \text { diet; } \mathrm{C}) \text { as detoxifying strategy }\end{array}$ \\
\hline $\begin{array}{l}\text { Deng et al. } \\
2010\end{array}$ & $\begin{array}{l}\text { Nile tilapia } \\
\text { (Oreochromisniloticus) }\end{array}$ & $\begin{array}{l}19 ; 85^{0} ; 245^{1} ; 638^{2} ; 793^{3} \text { and } \\
1,641^{4} \mathrm{\mu g} \mathrm{kg}^{-1}\end{array}$ & $\begin{array}{l}\mathrm{Y}^{\mathrm{t1}-\mathrm{tff} ;-4} \\
\mathrm{~L}^{\mathrm{t1}}=10^{0}, 16^{1}, 21^{2}, 24^{3} \text { and } \\
24^{4} \mu \mathrm{AFB} \mathrm{kg}^{-1} \text { liver } \\
\mathrm{L}^{\mathrm{tf}}=30^{0}, 33^{1}, 47^{2}, 44^{3} \text { and } \\
43^{4} \mu \mathrm{AFB} \mathrm{kg}_{1}^{-1} \text { liver }\end{array}$ & $\begin{array}{l}Y^{\mathrm{t} 1-\mathrm{t} t ; 0-4} \\
\mathrm{~L}^{\mathrm{t1}}=0.118^{0}, 0.065^{1}, 0.033^{2} \\
0.030^{3} \text { and } 0.015^{4} \\
\mathrm{~L}^{\mathrm{tf}}=0.353^{0}, 0.135^{1}, 0.074^{2} \\
0.055^{3} \text { and } 0.026^{4}\end{array}$ & ELISA & $\begin{array}{l}\text { - Initial weight: } 20 \mathrm{~g} \text {; } \\
\text { - } 20^{\text {tit }} \text { week study (sampling at week } 5^{\mathrm{t1}} \text { ) } \\
\text { - AF from mouldy peanut meal }\end{array}$ \\
\hline $\begin{array}{l}\text { Hessein et al. } \\
2014\end{array}$ & $\begin{array}{l}\text { Nile tilapia } \\
\text { (Oreochromisniloticus) }\end{array}$ & $\left(0,250^{1} \mathrm{mg} \mathrm{kg}^{-1}\right) \times$ Vit or $C$ & $\mathrm{M}^{1}=\mathrm{mg} \mathrm{kg}^{-1}$ & $M^{1}=0.407$ & & 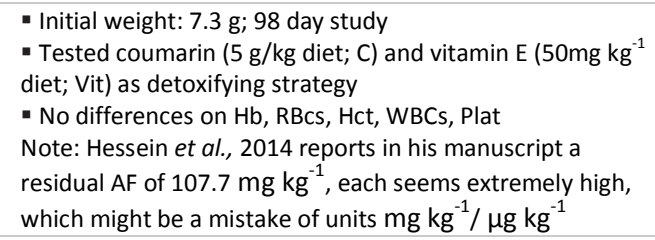 \\
\hline $\begin{array}{l}\text { Hussain et al. } \\
2017\end{array}$ & $\begin{array}{l}\text { Nile tilapia } \\
\text { (Oreochromisniloticus) }\end{array}$ & $\begin{array}{l}\left(0,2000^{1}, 4000^{2} \mathrm{mg} \mathrm{kg}^{-1}\right) \times \\
0.5 \% \text { and } 1 \% \mathrm{CB}\end{array}$ & $\mathrm{M}^{2}=0.087 \pm 1.32 \mu \mathrm{g} \mathrm{kg}^{-1}$ & $\mathrm{M}^{2} \sim 0$ & HPLC & $\begin{array}{l}\text { - Initial weight: } 4.5 \pm 0.4 \mathrm{~g} ; 10 \text { week study } \\
\text { - Tested calcium bentonite (CB) clay as detoxifying strategy; } \\
\text { - Tested CB significantly improved some parameters (WG, } \\
\text { HIS) } \\
\text { - CB significantly reduced bioaccumulation of } \text { AFB }_{1} \text { residues } \\
\text { in muscle tissues. }\end{array}$ \\
\hline $\begin{array}{l}\text { Mahfouz et al. } \\
2015\end{array}$ & $\begin{array}{l}\text { Nile tilapia } \\
\text { (Oreochromisniloticus) }\end{array}$ & $\begin{array}{l}20^{1} \text { and } 100^{2} \mu \mathrm{g} A \mathrm{AB}_{1} \mathrm{~kg}^{-1} \\
\text { feed }\end{array}$ & $\begin{array}{l}\mathrm{L} \\
1, \mathrm{t1}=5 \mu \mathrm{kg}^{-1} \\
1, \mathrm{t2}=8 \mu \mathrm{kg}^{-1}\end{array}$ & $\begin{array}{l}L^{1, t 1}=0.25 \\
L^{1,22}=0.4 \\
L^{2, t 1}=0.1\end{array}$ & TLC & $\begin{array}{l}\text { - Initial weight: } 35 \pm 0.50 \mathrm{~g} ; 6^{11} \text { or } 12^{12} \text { week studies } \\
\text { - Challenge test with Aeromonas hydrophila, IP } \\
\text { - Expression of liver } G P x \text { and GST down-regulated } \\
\text { - The ability to withstand } A \text {. hydrophila infection was }\end{array}$ \\
\hline
\end{tabular}




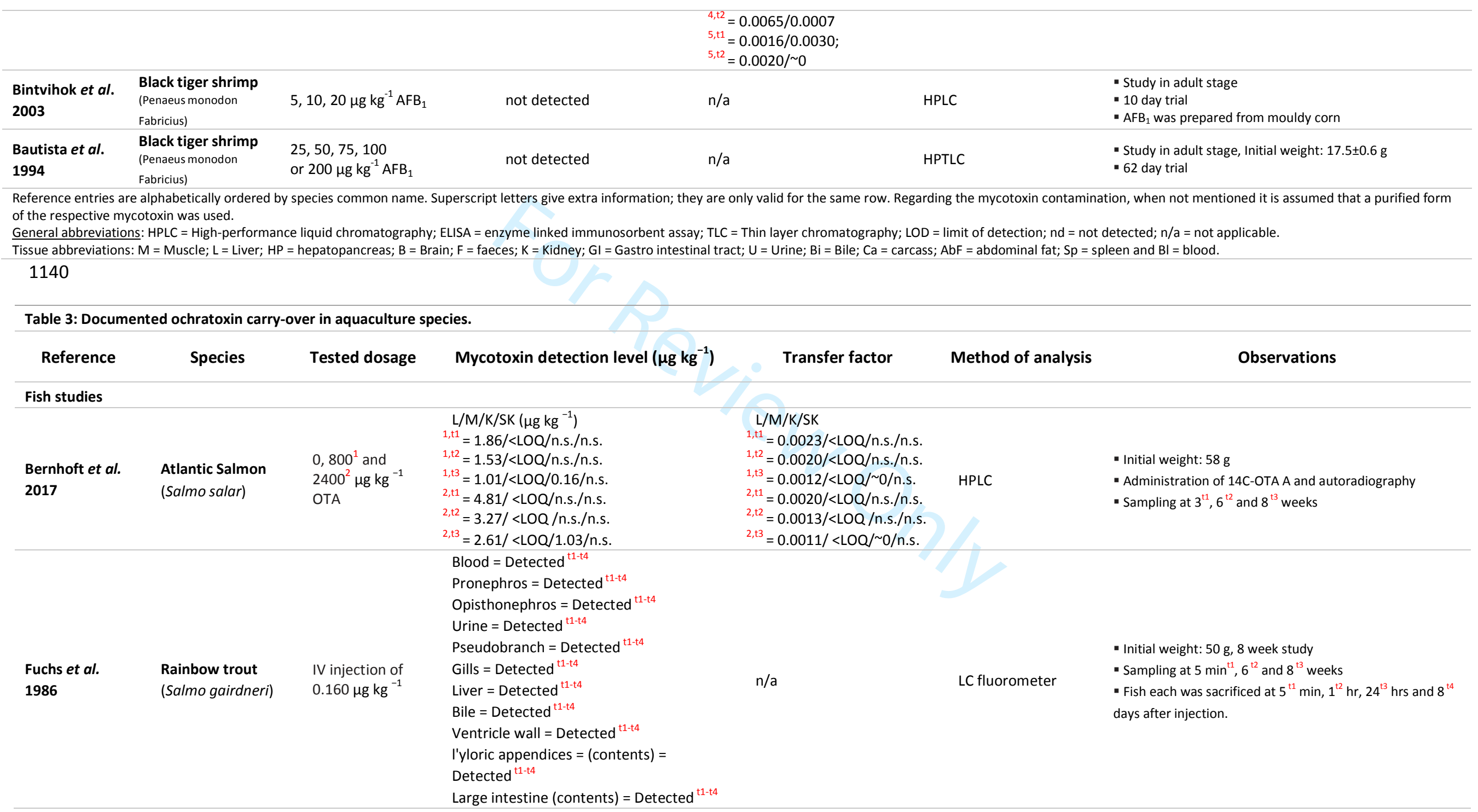


Splccn ("patches") = Detected $^{\text {t1-t4 }}$

Muscle (close to the myomeres) =

Detected $^{\text {t1-t2 }}$

Spinal cord $^{=}$Detected $^{\mathrm{t1-t3}}$

Fins $=$ Detected $^{\text {t1-t4 }}$

Skin $=$ Detected $^{\text {t1-t4 }}$

Muscles $=$ Detected $^{\text {t1-t }}$

Shrimp studies

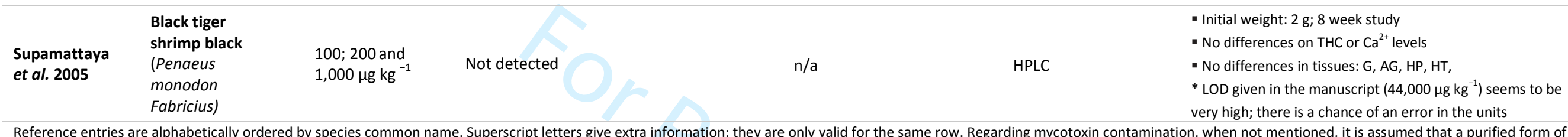

the respective mycotoxin was used.

General abbreviations: HPLC = High-performance liquid chromatography; $L C=$ liquid chromatography; $n / a=$ not applicable; $n . s$. not sampled

Tissue abbreviations: $\mathrm{M}=$ = Muscle; $\mathrm{L}=$ Liver; $\mathrm{K}=$ Kidney; $\mathrm{SK}=$ skin.

1141

1142

Table 4: Documented deoxynivalenol and/or fumonisin carry-over in aquaculture species.

\begin{tabular}{|c|c|c|c|c|c|c|}
\hline Reference & Species & Tested dosage & $\begin{array}{c}\text { Mycotoxin detection level ( } \mu \mathrm{g} \\
\mathrm{kg}^{-1} \text { ) }\end{array}$ & Transfer factor & Method of analysis & Observation \\
\hline \multicolumn{7}{|l|}{ Fish studies } \\
\hline $\begin{array}{l}\text { Bernhoft et al. } \\
2017\end{array}$ & $\begin{array}{l}\text { Atlantic salmon } \\
\text { (Salmo salar) }\end{array}$ & $\begin{array}{l}0 ; 2000^{1} \text { and } \\
6000^{2} \mu \mathrm{kg}^{-1} \\
\text { DON }\end{array}$ & $\begin{aligned} & \mathrm{L} / \mathrm{M} / \mathrm{K} / \mathrm{SK}\left(\mu \mathrm{gg}^{-1}\right) \\
& 1, \mathrm{t} 1 \mathrm{t}=12 \cdot 2 / 5 \cdot 6 / \text { n.s. } / \text { n.s. } \\
& 1, \mathrm{t2}=12 \cdot 8 / 8 \cdot 5 / \text { n.s. } / \text { n.s. } \\
& 1, \mathrm{t3}=18 \cdot 1 / 6 \cdot 0 / 12 \cdot 3 / \text { n.s. } \\
& 2, \mathrm{t1}=9 \cdot 6 / 10 \cdot 3 / \text { n.s. } / \text { n.s. } \\
& 2, \mathrm{t2}=20 \cdot 2 / 17 \cdot 3 / \text { n.s. } / \text { n.s. } \\
& 2, \mathrm{t3}=28 \cdot 6 / 18 \cdot 6 / 16 \cdot 8 / 20.8\end{aligned}$ & $\begin{aligned} & \mathrm{L} / \mathrm{M} / \mathrm{K} / \mathrm{SK} \\
& 1, \mathrm{t} 1 \mathrm{t}=0.0061 / 0.0028 / \text { n.s. } / \text { n.s. } \\
& 1, \mathrm{t2}=0.0064 / 0.0042 / \text { n.s. } / \text { n.s. } \\
& 1, \mathrm{t3}= 0.0091 / 0.003 / 0.0061 / \text { n.s. } \\
& 2, \mathrm{t1}=0.0016 / 0.0017 / \text { n.s. } / \text { n.s. } \\
& 2, \mathrm{t2}=0.0034 / 0.0029 / \text { n.s. } / \text { n.s. } \\
& 2, \mathrm{t3}=0.0048 / 0.0031 / 0.0028 / 0.0035\end{aligned}$ & HPLC & $\begin{array}{l}\text { - Initial weight: } 58 \mathrm{~g}, 8 \text { week study; } \\
\text { - Sampling at } 3^{\text {t1 }}, 6^{\text {t2 }} \text { and } 8^{\text {t3 }} \text { weeks }\end{array}$ \\
\hline
\end{tabular}




\begin{tabular}{|c|c|c|c|c|c|c|}
\hline $\begin{array}{l}\text { Nácher-Mestre } \\
\text { et al. } 2015\end{array}$ & $\begin{array}{l}\text { Atlantic salmon } \\
\text { (Salmo salar) }\end{array}$ & $\begin{array}{l}\text { Diet } 1=22.4 \\
\text { DON + 148 FUM } \\
\text { Diet } 2=19.4 \\
\text { DON + 754 FUM } \\
\text { Diet } 3=23.1 \\
\text { DON + 112 FUM }\end{array}$ & Not detected & n/a & LC-ESI-MS/MS & $\begin{array}{l}\text { - } 6 \text { month trial } \\
\text { - Initial body weight of } 228 \pm 5 \mathrm{~g} \\
\text { - Minor amounts of T-2 found and 15-ACDON and OTA } \\
\text { detected }\end{array}$ \\
\hline $\begin{array}{l}\text { Pietsch et al. } \\
2014\end{array}$ & $\begin{array}{l}\text { Common carp } \\
\text { (Cyprinus carpio) }\end{array}$ & $\begin{array}{l}352^{1}, 619^{2} \text { and } \\
953^{3^{\prime}} \mu \mathrm{kg}^{-1} \mathrm{DON}\end{array}$ & $\begin{array}{l}\text { Muscle samples }\left(\mu \mathrm{kg}^{-1}\right) \\
1^{1}=0.6 ;^{1, \mathrm{RP}}=1.4 \\
=1.3 ; ;^{2, \mathrm{RP}}=0.7 \\
{ }^{3}=1.2 ; ;^{3, \mathrm{RP}}=0.0\end{array}$ & $\begin{array}{l}\text { Muscle samples } \\
1^{1}=0.0017 ; ;^{1, \mathrm{RP}}=0.0040 \\
{ }^{2}=0.0021 ; ;^{1, \mathrm{RP}}=0.0011 \\
{ }^{3}=0.0013 ; ;^{1, \mathrm{RP}}=0\end{array}$ & HPLC & $\begin{array}{l}\text { - Raised from eggs (average initial weight } 36 \mathrm{~g} \text { ), } 4 \text { week } \\
\text { study } \\
\text { - Additional } 2 \text { weeks of feeding uncontaminated diet - } \\
\text { recovery period }{ }^{\mathrm{PP}}\end{array}$ \\
\hline $\begin{array}{l}\text { Nácher-Mestre } \\
\text { et al. } 2015\end{array}$ & $\begin{array}{l}\text { Gilthead sea } \\
\text { bream (Sparus } \\
\text { aurata) }\end{array}$ & $\begin{array}{l}\text { Diet } 1=79.2 \\
\text { DON }+8.115- \\
\text { AcDON } \\
\text { Diet } 2=53.5 \\
\text { DON + 13.6 15- } \\
\text { AcDON +6.4 FUM }\end{array}$ & Not detected & $n / a$ & LC-ESI-MS/MS & $\begin{array}{l}\text { - } 8 \text { month trial } \\
\text { - Initial body weight of } 15 \mathrm{~g} \text { up to } 296-320 \mathrm{~g}\end{array}$ \\
\hline $\begin{array}{l}\text { Huang et al. } \\
2018\end{array}$ & $\begin{array}{l}\text { Grass carp } \\
\text { (Ctenopharyngodon } \\
\text { idella) }\end{array}$ & $\begin{array}{l}27 ; 318^{1} ; 636^{2} \\
922^{3} ; 1,243^{4} \text { and } \\
1,515^{5} \mathrm{Hg} \mathrm{kg}^{-1} \\
\text { DON }\end{array}$ & $\begin{array}{l}\mathrm{Pl}=16.46^{4} ; 17.64^{5} \mathrm{\mu g} \mathrm{kg}^{-1} \mathrm{tissue} \\
\mathrm{Ml}=15.90^{3} ; 18.54^{4} ; 20.34^{5} \mu \mathrm{kg}^{-1} \\
\text { tissue } \\
\text { DI }=18.91^{3} ; 24.40^{4} ; 28.82^{5} \mathrm{\mu g} \mathrm{kg}^{-1} \\
\text { tissue }\end{array}$ & $\begin{array}{l}\mathrm{Pl}=0.013^{4} ; 0.012^{5} \\
\mathrm{MI}=0.017^{3} ; 0.015^{4} ; 0.013^{5} \\
\mathrm{DI}=0.021^{3} ; 0.020^{4} ; 0.019^{5}\end{array}$ & HPLC & $\begin{array}{l}\text { - Initial weight: } 12.17 \pm 0.01 \mathrm{~g} \text {; } 60 \text { days trial } \\
\text { - Malformations: missing of pelvic fin"; caudal fin } \\
\text { deformity"; operculum } \\
\text { • "the safe dose of DON for grass carp were all estimated } \\
\text { to be } 318 \mathrm{\mu g} / \mathrm{kg} \text { diet"; Huang et al. } 2018\end{array}$ \\
\hline \multicolumn{7}{|l|}{ Shrimp studies } \\
\hline $\begin{array}{l}\text { Supamattaya } \\
\text { et al. } 2005\end{array}$ & $\begin{array}{l}\text { Black tiger } \\
\text { shrimp black } \\
\text { (Penaeus } \\
\text { monodon } \\
\text { Fabricius) }\end{array}$ & $\begin{array}{l}500 ; 1,000 \text { and } \\
2,000 \mathrm{\mu g} \mathrm{kg}^{-1} \\
\text { DON }\end{array}$ & Not detected & $\mathrm{n} / \mathrm{a}$ & HPLC & $\begin{array}{l}\text { - Initial weight: } 2 \mathrm{~g} ; 8 \text { week study } \\
\text { - No differences on THC or } \mathrm{Ca}^{2+} \text { levels } \\
\text { - No differences in tissues: } \mathrm{G}, \mathrm{AG}, \mathrm{HP}, \mathrm{HT} \text {, } \\
\text { * LOD given in the manuscript }\left(50,000 \mu \mathrm{k} \mathrm{kg}^{-1}\right) \text { seems to be } \\
\text { very high; there is a chance of an error in the units }\end{array}$ \\
\hline $\begin{array}{l}\text { Trigo-Stockli } \\
\text { et al. } 2000\end{array}$ & $\begin{array}{l}\text { Pacific white } \\
\text { shrimp } \\
\text { (Litopenaeus } \\
\text { vannamei) }\end{array}$ & $\begin{array}{l}0,200,500 \text { and } \\
1,000 \mu \mathrm{kg}^{-1} \\
\text { DON }\end{array}$ & Not detected & $\mathrm{n} / \mathrm{a}$ & HPLC & $\begin{array}{l}\text { - Initial weight: } 1.7 \pm 0.05 \mathrm{~g}, 16 \text { week study (sampling at } 4 \text {, } \\
\text { 8, } 12 \text { and } 16 \text { weeks) } \\
\text { - Naturally contaminated hard red winter wheat }\end{array}$ \\
\hline $\begin{array}{l}\text { Deng et al. } \\
2017\end{array}$ & $\begin{array}{l}\text { Pacific white } \\
\text { shrimp } \\
\text { (Litopenaeus } \\
\text { vannamei) }\end{array}$ & $\begin{array}{l}0 ; 500^{1} ; 1,200^{2} ; \\
2,400^{3} ; 4,800^{4} ; \\
12,200^{5} \mathrm{\mu g} \mathrm{kg}^{-1} \\
\mathrm{~T}-2\end{array}$ & $\begin{array}{l}{ }_{\mathrm{HP}}^{\mathrm{m}}=17.52 \pm 2.87^{4} \mathrm{ng} \mathrm{g}^{-1} \\
{ }_{\mathrm{HP}} \mathrm{m}=48.61 \pm 3.13^{5} \mathrm{ng} \mathrm{g}^{-1}\end{array}$ & $\mathrm{n} / \mathrm{a}$ & TSQ & $\begin{array}{l}\text { - Initial weight: } 8.5 \pm 0.5 \mathrm{~g} ; 20 \text { days study } \\
\text { - Dietary concentrations correspond to } 1 / 50,1 / 20,1 / 10 \text {, } \\
1 / 5 \text { and } 1 / 2 \text { (Wang et al. 2015). }\end{array}$ \\
\hline
\end{tabular}




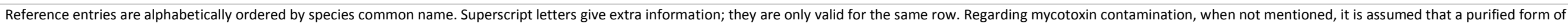
the respective mycotoxin was used.

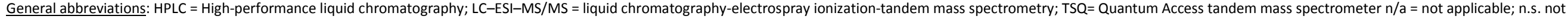
sampled

Tissue abbreviations: $\mathrm{M}=$ Muscle; $\mathrm{L}=$ Liver; $\mathrm{K}=$ Kidney; $\mathrm{SK}=$ skin.

1143

Table 5: Documented zearalenone carry-over in aquaculture species.

\begin{tabular}{|c|c|c|c|c|c|c|}
\hline Reference & Species & Tested dosage & Mycotoxin detection level $\left(\mu \mathrm{g} \mathrm{kg}^{-1}\right)$ & Transfer factor & Method of analysis & Observations \\
\hline \multicolumn{7}{|l|}{ Fish studies } \\
\hline $\begin{array}{l}\text { Pietsch et al. } \\
2015\end{array}$ & $\begin{array}{l}\text { Common Carp } \\
\text { (Cyprinus carpio } \\
\text { L.) }\end{array}$ & $\begin{array}{l}0 ; 332^{1} ; 621^{2} \text { and } \\
797^{3} \mathrm{\mu g} \mathrm{kg}^{-1}\end{array}$ & 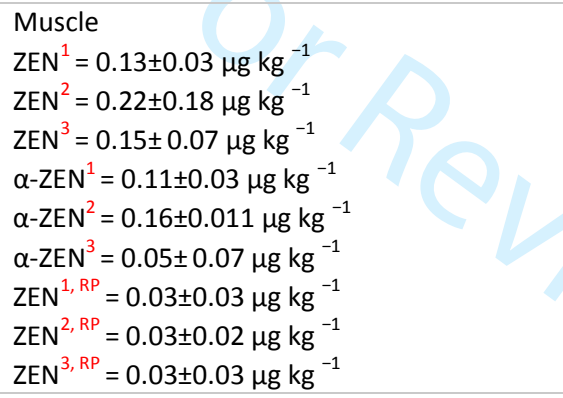 & $\begin{array}{l}\text { Muscle } \\
\mathrm{ZEN}^{1} \sim 0 \\
\mathrm{ZEN}^{2} \sim 0 \\
\mathrm{ZEN}^{3} \sim 0 \\
\alpha-\mathrm{ZEN}^{1} \sim 0 \\
\alpha-\mathrm{ZEN}^{2} \sim 0 \\
\alpha-\mathrm{ZEN}^{3} \sim 0 \\
\mathrm{ZEN}^{1, \mathrm{RP}} \sim 0 \\
\mathrm{ZEN}^{2, \mathrm{RP}} \sim 0 \\
\mathrm{ZEN}^{3, \mathrm{RP}} \sim 0\end{array}$ & HPLC & $\begin{array}{l}\text { - Raised from egg with } 12-16 \mathrm{~cm} \text { in length } \\
\text { - } 4 \text { week study } \\
\text { - } \alpha \text {-ZEN were not detectable after recovery period } \\
\text { ( } 2 \text { weeks) and ZEN was detected at } 0.03 \mu \mathrm{g} \mathrm{kg}^{-1} \\
\text { dry weight for all treatments }\end{array}$ \\
\hline $\begin{array}{l}\text { Woźny et al. } \\
2015\end{array}$ & $\begin{array}{l}\text { Rainbow trout } \\
\text { (Oncorhynchus } \\
\text { mykiss) }\end{array}$ & $1,810 \mu \mathrm{g} \mathrm{kg}^{-1}$ & $\begin{array}{l}\text { Intestines } \\
\text { ZEN }=732.2 \mu \mathrm{g} \mathrm{kg}^{-1} \\
\alpha-Z E N=10.7 \mu \mathrm{g} \mathrm{kg}^{-1} \\
\mathrm{~L}=\text { residual ZEN and } \alpha \text {-ZEN in all sampled fish }\end{array}$ & $\begin{array}{l}\text { Intestines } \\
\text { ZEN }=0.40 \\
\alpha-Z E N=0.0059\end{array}$ & & $\begin{array}{l}\text { - Initial weight: } 250 \mathrm{~g} \text {, all females; } 71 \text { day study } \\
\text { - Some animals were identified as males } \\
\text { - ZEN was detected }\left(<5.0 \mu \mathrm{g} \mathrm{kg}^{-1}\right) \text { in all female } \\
\text { ovaries }\end{array}$ \\
\hline $\begin{array}{l}\text { Woźny et al. } \\
2017\end{array}$ & $\begin{array}{l}\text { Rainbow trout } \\
\text { (Oncorhynchus } \\
\text { mykiss) }\end{array}$ & $\begin{array}{l}1 \mathrm{mg} \mathrm{kg}^{-1} \text { of body } \\
\text { mass }\end{array}$ & $\begin{array}{l}\text { ZEN/ } \alpha-Z E N / \beta-Z E N\left(\mu \mathrm{kg}^{-1}\right) \\
\mathrm{I}^{48 \mathrm{~h}}=\sim 1500 / \sim 600 /- \\
\mathrm{I}^{96 \mathrm{~h}}=\sim 1500 / \sim 900 /- \\
\mathrm{L}^{48 \mathrm{~h}}=\sim 700 / \sim 100 / \sim 500 \\
\mathrm{~L}^{96 \mathrm{~h}}=<200 /<20 / \sim 0 \\
\mathrm{O}^{48 \mathrm{~h}}=321 / \sim 100 /- \\
\mathrm{O}^{96 \mathrm{~h}}=<100 /<100 /- \\
\mathrm{Oo}^{48 \mathrm{~h}}=\sim 25 / \sim 10 /- \\
\mathrm{Oo}^{96 \mathrm{~h}}=<5 /<5 /- \\
\mathrm{P}^{48 \mathrm{~h}}=\sim 10 / \sim 5 /- \\
\mathrm{P}^{96 h}=\sim 0 / \sim 0 /- \\
\mathrm{M}^{48 \mathrm{~h}}=\sim 5 / \sim 5 /- \\
\mathrm{M}^{96 \mathrm{~h}}=\sim 3 / \sim 3 /-\end{array}$ & $\begin{array}{l}\text { ZEN/ } \alpha-Z E N / \beta-Z E N\left(\mu \mathrm{kg}^{-1}\right) \\
\mathrm{I}^{48 \mathrm{~h}}=1.5 / 0.6 /- \\
\mathrm{I}^{96 \mathrm{~h}}=1.5 / 0.9 /- \\
\mathrm{L}^{48 \mathrm{~h}}=0.7 / 0.1 / 0.5 \\
\mathrm{~L}^{96 \mathrm{~h}}=<0.2 /<0.02 / \sim 0 \\
\mathrm{O}^{48 \mathrm{~h}}=0.321 / 0.1 /- \\
\mathrm{O}^{96 \mathrm{~h}}=<0.1 /<0.1 /- \\
\mathrm{Oo}^{48 \mathrm{~h}}=\sim 0.025 / \sim 0.01 /- \\
\mathrm{Oo}^{96 \mathrm{~h}}=<0.005 /<0.005 /- \\
\mathrm{P}^{48 \mathrm{~h}}=\sim 0.01 / \sim 0.005 /- \\
\mathrm{P}^{96 \mathrm{~h}}=\sim 0 / \sim 0 /- \\
\mathrm{M}^{48 \mathrm{~h}}=\sim 0.005 / \sim 0.005 /- \\
\mathrm{M}^{96 \mathrm{~h}}=\sim 0.003 / \sim 0.003 /-\end{array}$ & HPLC-FLD & $\begin{array}{l}\text { - Initial weight: } 1274 \pm 162 \mathrm{~g} \text {, all mature females } \\
\text { - Objective was to study the ZEN carry-over to } \\
\text { eggs } \\
\text { - Administration on ZEN - oral (bolus) } \\
\text { - Sampling periods: } 2,6,12,24,48,72,96 \mathrm{~h} \\
\text { - Verified the presence of ZEN and } \alpha \text {-ZEN in } \\
\text { commercial fish roe } \\
\text { - “Contamination of fish roe with zearalenone } \\
\text { residuals is unlikely to pose a health risk to } \\
\text { consumers, but their potential to transfer to } \\
\text { somatic cells in fish ovaries may be of concern for } \\
\text { aquaculture", Woźny et al. } 2017\end{array}$ \\
\hline
\end{tabular}




\section{Shrimp - no studies}

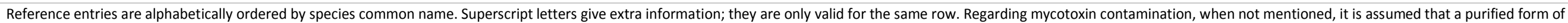
the respective mycotoxin was used.

General abbreviations: HPLC = High-performance liquid chromatography; HPLC-FLD = High-performance liquid chromatography with fluorescence detection

Tissue abbreviations: $\mathrm{I}=$ Intestines; $\mathrm{O}=$ Ovaries; Oo = Oocytes; $\mathrm{P}=$ Plasma, $\mathrm{M}=$ Muscle

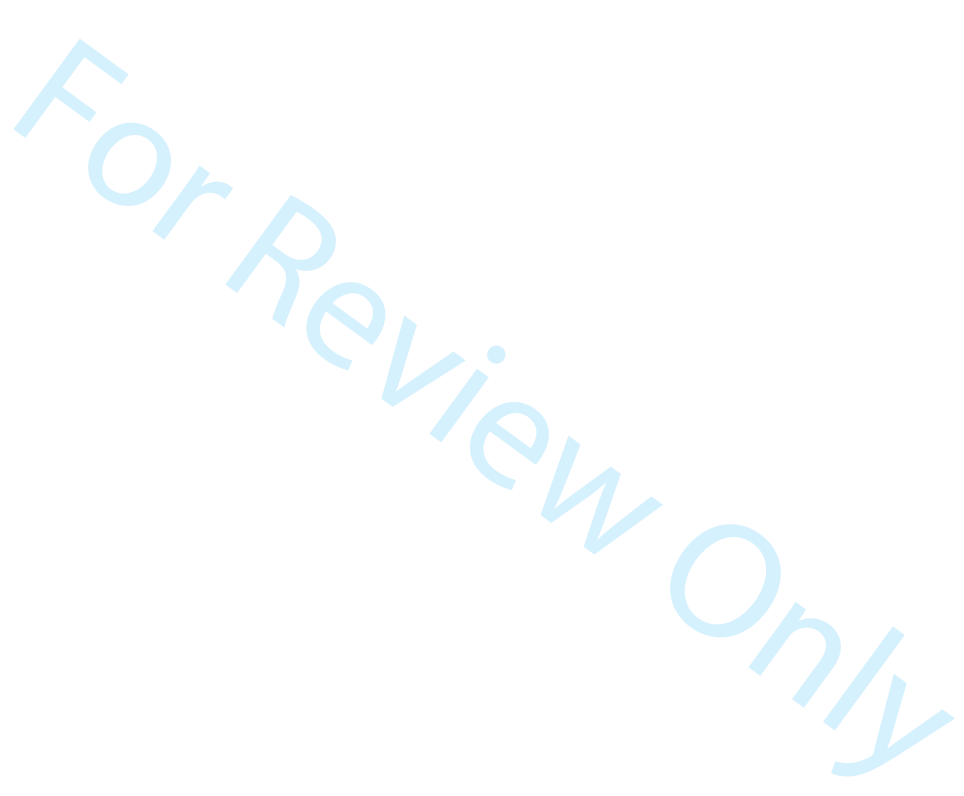




\begin{tabular}{|c|c|c|c|c|c|c|c|c|}
\hline Reference & $\begin{array}{l}\text { Sampling } \\
\text { Country } \\
\text { (region) }\end{array}$ & \# samples / Species & Sample origin & $\begin{array}{l}\text { Target } \\
\text { mycotoxin } \\
\text { analysed } \\
\text { in tissue }\end{array}$ & $\begin{array}{c}\text { Tissue } \\
\text { sampled }\end{array}$ & Mycotoxin detection level ( $\mu \mathrm{g} \mathrm{kg}^{-1}$ ) & $\begin{array}{l}\text { Method } \\
\text { of } \\
\text { analysis }\end{array}$ & Observations \\
\hline $\begin{array}{l}\text { Tolosa et al. } \\
2013\end{array}$ & $\begin{array}{l}\text { Spain } \\
\text { (Valencia) }\end{array}$ & $\begin{array}{l}\mathrm{N}_{\mathrm{t}}=19 \\
\mathrm{n}=9^{\mathrm{SB}} \text { Seabass }^{\mathrm{AQ}} \\
\mathrm{n}=5^{\mathrm{GSB}} \text { Seabream }^{\mathrm{AQ}} \\
\mathrm{n}=3 \text { (mackerel, hake, }^{\text {(mad }} \text { cod) } \\
\mathrm{WF} \\
\mathrm{n}=1^{\top} \text { Tilapia }^{\mathrm{AQ}} \\
\mathrm{n}=1^{\mathrm{P}} \text { Panga }^{\mathrm{AQ}}\end{array}$ & $\begin{array}{l}\text { Aquaculture }^{\mathrm{AQ}} \\
\text { - Seabass } \\
\text { Spain (Cartagena, Murcia) } \\
\text { Greece (Argolis) } \\
\text { - Seabream } \\
\text { Spain and Greece (Argolis); } \\
\text { - Tilapia } \\
\text { China } \\
\text { - Pangasius } \\
\text { Vietnam } \\
\text { Wild fisheries } \\
\text { WF } \\
\text { - Hake } \\
\text { Southeast Atlantic } \\
\text { - Cod and Mackerel } \\
\text { Northwest Atlantic }\end{array}$ & $\begin{array}{l}\text { BEA } \\
\text { ENA } \\
\text { ENA1 } \\
\text { ENB } \\
\text { ENB1 }\end{array}$ & Muscle & 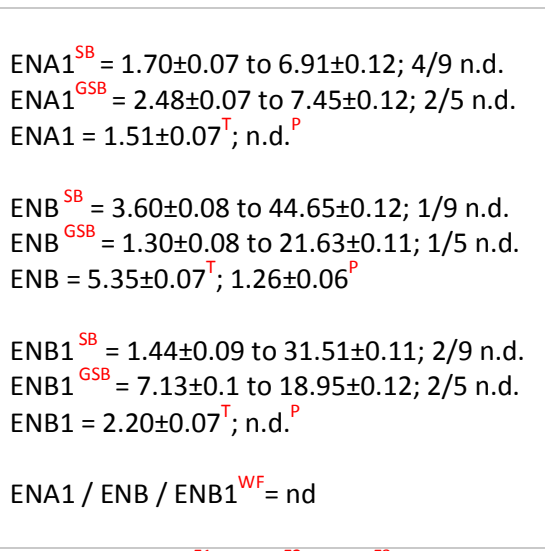 & $\begin{array}{l}\text { LC- } \\
\text { MS/MS }\end{array}$ & $\begin{array}{l}\text { - ENA and BEA were not } \\
\text { detected in samples analysed } \\
\text { - Seabass (Dicentrarchus labrax) } \\
\text { - Seabream (Sparus aurata) } \\
\text { - Aquaculture } \\
\text { - Wild fisheries }\end{array}$ \\
\hline $\begin{array}{l}\text { Woźny et } \\
\text { al. } 2013\end{array}$ & $\begin{array}{l}\text { Poland } \\
\text { (North-eastern } \\
\text { region) }\end{array}$ & $\begin{array}{l}\mathrm{N}_{\mathrm{t}}=9 \\
3 \text { samples from } 3 \\
\text { different farms }\end{array}$ & $\begin{array}{l}\text { Poland } \\
\text { (North-eastern region) }\end{array}$ & ZEN & $\begin{array}{l}\text { Intestine } \\
\text { Liver } \\
\text { Ovary } \\
\text { Muscle }\end{array}$ & 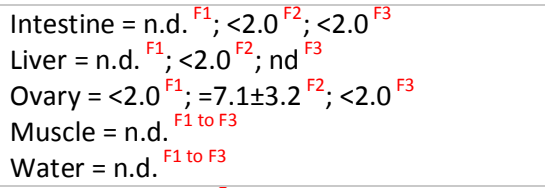 & HPLC & \\
\hline $\begin{array}{l}\text { Woźny et } \\
\text { al. } 2017\end{array}$ & $\begin{array}{l}\text { Poland } \\
2013^{T 1} \\
2014^{T 2} \\
2015^{T 3}\end{array}$ & $\begin{array}{l}\mathrm{n}=35 \\
\text { (acquired from }^{\mathrm{A}} \\
\text { hatcheries) }^{\mathrm{AQH}} \\
\mathrm{n}=6 \\
\text { (from supermarket) }^{\mathrm{S}}\end{array}$ & $\begin{array}{l}\text { Norway } \\
\text { Poland }\end{array}$ & $\begin{array}{l}\text { ZEN, } \alpha-Z E L, \\
\beta-Z E L\end{array}$ & $\begin{array}{l}\text { Ovary }^{\text {Ov }} \\
\text { Oocytes } \\
\text { Salted roe } \\
\text { Sr }\end{array}$ & 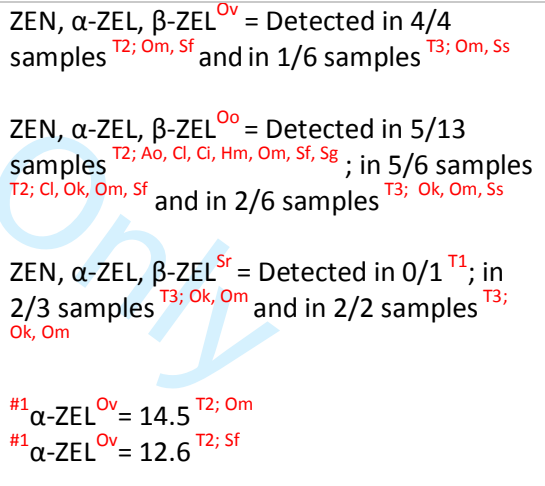 & HPLC-FLD & $\begin{array}{l}\text { Species sampled: } \\
\text { Acipenser oxyrinchus }{ }^{\mathrm{AO}} \\
\text { Coregon lavaretus }^{\mathrm{C}} \\
\text { Ctenopharyngodon idella }^{\mathrm{Ci}} \\
\text { Hypophthalmichthys molitrix }^{\mathrm{Hm}} \\
\text { Oncorhynchus mykiss } \\
\text { Salvelinus fontinalis }^{\mathrm{Sf}} \\
\text { Silurus glanis } \\
\text { Oncorhynchus keta } \\
\text { Salmo }^{\mathrm{Ok}} \\
\text { salar }^{\mathrm{ss}}\end{array}$ \\
\hline & & & & & & $\begin{array}{l}\text { All mycotoxin levels detected below LOD } \\
\text { (ZEN, a-ZEL, and ß-ZEL were 5.0, 3.0, and } \\
12.0 \text { ug kg-1) except }{ }^{\# 1}\end{array}$ & & \\
\hline
\end{tabular}

Reference entries are alphabetically ordered by publication first author. Superscript letters give extra information; they are only valid for the same row.

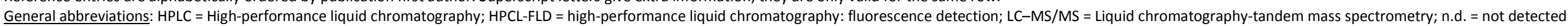
Mycotoxins: $B E A=$ beauvericin; ENA = enniatins; ENA1 = enniatin A1; ENA2 = enniatin A2; ENB = enniatin B; ENB1 = enniatin B1; ZEN = zeralenone; $\alpha-Z E L=$ alpha-Zearalenol; $\beta-Z E L=$ beta-Zearalenol. 


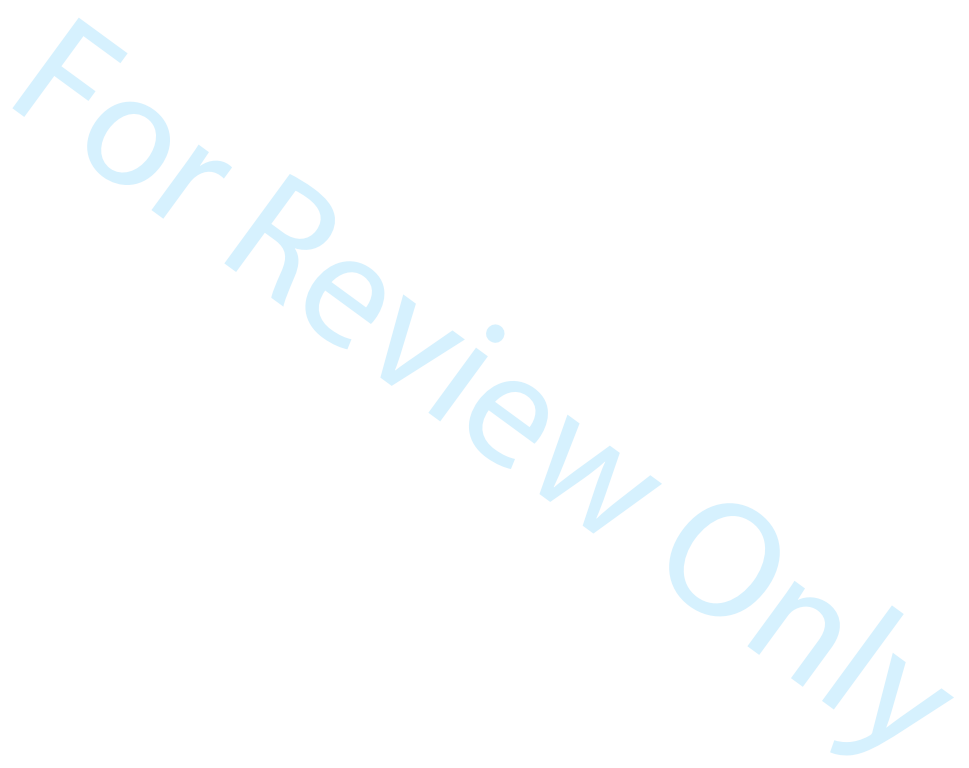

